\title{
MR. JUSTICE DOUGLAS: HIS INFLUENCE ON CORPORATE AND SECURITIES REGULATION
}

\author{
RICHARD W. JENNINGS*
}

THE silver anniversary of Mr. Justice Douglas's distinguished service on the United States Supreme Court is a felicitous occasion for assessing his impact on the law of corporation finance and securities regulation, particularly here in the pages of the Yale Law Journal. It was at the Yale Law School that the then Professor Douglas first gained recognition as a gifted teacher and craftsman in the field of Corporation Law and Finance; and it was from that base that he launched a meteoric career which led to his appointment to a seat on our highest court in 1939 at the age of 40 . Mr. Justice Douglas has indeed brought honor to Yale as Yale now honors him.

This is a study of three periods in the life of the Justice. The first is that of Professor Douglas, law teacher; it began shortly after his graduation from the Columbia Law School in 1925 at the age of 26 and ended when he left the faculty of the Yale Law School in 1934 to join the staff of the Securities and Exchange Commission. In terms of years his law teaching career was brief; but we shall see that it was remarkably rich in intellectual achievement.

The second deals with his government service with the Securities and Exchange Commission. Again his SEC career was amazingly short - a matter of only five years. It began in October, 1934 when Douglas took leave from his classes at the Yale Law School to become director of the Commission's study of protective committees and reorganization practices under the Securities Act of 1933. Under Douglas this investigation and study culminated in a painstaking and devastating exposure of legal and corporate skullduggery in reorganizations. In recognition of this contribution he was appointed to membership on the Commission in January, 1936, to fill the vacancy created by the resignation of Joseph $\mathrm{P}$. Kennedy, who had served as the Commission's first Chairman. Membership on the Commission gave him the opportunity to participate more directly in the processes of securities regulation. He continued to head up the Protective Committee Study; but he also assumed direction of the Commission's important Division of Trading and Exchanges, the watchdog agency of the stock exchanges, whose operations up to that time had not been greatly affected by regulation under the Securities Exchange Act of 1934. This vantage point enabled him to make an intensive study of the effectiveness of Exchange and SEC controls over trading. When in September, 1937, James M. Landis resigned as Chairman of the Commission and Douglas was elected to that post by the Commission, he was ready with a dynamic plan for the administrative control of finance. That program, carried out under his leadership, ultimately led to sweeping legislative and adminis-

*Coffroth Professor of Law, University of California School of Law, Berkeley. 
trative reforms affecting corporate reorganizations, stock exchanges, and the over-the-counter market. More importantly, it established the guidelines of federal securities regulation which continue to this day. Basically, Douglas advocated the principle of self-regulation by the securities industry under strong SEC supervision; in certain areas, however, where fraud prevention and disclosure were insufficient, he was insistent that the Commission should undertake such direct regulation of the industry as the protection of investors and the public interest demanded.

The third and continuing period spans Mr. Justice Douglas's quarter century of service as a member of the Court. In view of the grave constitutional issues which have occupied the attention of the Court during the greater part of this period it is perhaps not surprising that problems of corporate and financial law have tended somewhat to pale in significance. Nevertheless, in his judicial role Mr. Justice Douglas, over the years, has continued to exert a powerful influence in shaping the law in this area. No Supreme Court Justice, not even Mr. Justice Brandeis, ever brought to the court such expertise and deep understanding of the problems of corporate and financial law; none has left such a personal imprint upon the law through opinions which now stand as judicial landmarks in the unfolding law of corporate and securities regulation.

\section{Impact on Legal Education}

When William O. Douglas graduated from the Columbia Law School in 1925, second in his class and an editor of the Columbia Law Review, he immediately plunged into private practice with the crack Wall Street law firm of Cravath, Henderson \& De Gersdorf. ${ }^{1}$ This was no ordinary law firm. The Cravath firm and the "Cravath system" 2 for training young lawyers was unsurpassed for anyone who wanted an exposure in depth to the mysteries of corporation law and finance. As Robert T. Swaine put it: "The firm's practice, even in litigation, has dealt primarily with corporate and financial problems, and the character of the work from year to year has been increasingly determined by national economic conditions. Cycles of security issues in boom times have been followed by cycles of receivership and reorganizations in times of depression. ..."3 Thus each period of boom and bust exposed a wide range of problems arising during the life cycle of many corporations - from promotion to insolvency and reorganization.

Douglas's tenure with the Cravath firm was short, lasting only fourteen months. ${ }^{4}$ But this brief encounter with the dynamics of law practice must

1. A fascinating two-volume history of the Cravath firm has been written by SwAINE, The Cravath Firm and Its Predecessors-1819-1947 (1948) [hereinafter cited as SwAINE].

2. For a description of the Cravath system and techniques of training associates, see 2 SWAINE 1-12, 124-32 and passim.

3. 2 id. at 1 .

4. 2 id. at xl. He was with the firm from Sept. 15, 1925-Jan. 28, 1926 and Oct. 1, 1926-June 30, 1927. 
have deepened his interest in the economic and social implications of the law in action.

Although we do not know very much about the type of corporate problems to which he was exposed we do know that he became involved in one of the most fascinating bankruptcy reorganizations on record. For the Cravath firm was deeply engrossed in the 1925-28 reorganization of the Chicago, Milwaukee \& St. Paul Railway Co., one of the biggest receiverships in American history and destined to become a cause célèbre on the abuses of receiverships. ${ }^{5}$ Paul D. Cravath, as counsel for Kuhn, Loeb \& Co., the St. Paul bankers, backed up by Swaine and "a corps of senior and junior associates," was masterminding the reorganization. ${ }^{6}$ Douglas was apprenticed to Swaine and became a member of the "team." When a new corporation was organized in Delaware to receive the properties of the debtor corporation upon the foreclosure sale, he was one of the three Cravath associates who became its first directors and officers. ${ }^{7}$

Along with what must have been a grueling schedule at Cravath, Douglas started teaching separate courses on Bankruptcy and Partnership at the Columbia Law School. ${ }^{8}$ A Columbia Law classmate, Carrol M. Shanks, who was associated with the Wall Street firm of Root, Clark, Howland \& Ballantine, also started to teach a Seminar in Business Organizations at Columbia." Together they plunged into a project looking ultimately toward a drastic reorganization of law school materials on Business Units along functional lines. This collaboration continued when Douglas joined the Yale Law Faculty in $1928 .{ }^{10}$

Apparently Douglas and Shanks quickly reached the conclusion that law school training in the corporate field was at least a generation behind the

5. For an economic and social history of the St. Paul receivership and reorganization, see Lowenthal, The Investor Pays (1933). This receivership generated an investigation before the Interstate Commerce Commission, Committees of Congress and numerous court proceedings. See Investigation of Chicago, M. \& St. P. R.R., 131 I.C.C. 615 (1928); Reorganization, 131 I.C.C. 673 (1928) ; Jameson v. Guaranty Trust Co. of New York, 20 F.2d 808 (7th Cir. 1927), cert. denied, 275 U.S. 569 (1927) ; United States v. Chicago, M. \& St. P. R.R., 282 U.S. 311 (1931). For an account of the St. Paul reorganization through the eyes of Swaine, see 2 SwarNe 418-31, 546-47.

6. 2 Swanne 419 n:2.

7. Swaine adds the delightful tidbit: "[John J.] McCloy was the president, and several of the City papers published his picture-youthful, stern-visaged, with army pompadour and captain's uniform-as that of the youngest American railroad president." 2 SwAINE 425 n:1.

8. Association of American Law Schools, Directory of Teachers in Member ScHoors 21 (1925); 23 (1926). Evidently the second semester of the 1925-26 year was devoted fully to teaching and research. After another year of dividing his time between teaching and practice Douglas turned his back on private practice for a law teaching career.

9. AALS, DiRECTORY OF TEACHERS 67 (1925); id. at 72 (1926).

10. Mr. Shanks also joined the Yale Law Faculty, one year later. After one year at Yale, Shanks returned to law practice but the collaboration continued until 1931-32 when the two co-authored four casebooks on Business Units. 
times. In most law schools, in the midtwenties, there were separate courses in agency and partnership and only one course devoted to corporation law. In the law school world, the corporation was portrayed as a rather uncomplicated form of business unit. It had common stock; each share had one vote; and cumulative voting was an aberration. The board of directors was selected and elected by the shareholders exercising their electoral franchise and the board always "managed" the corporation. The three most widely-used case books devoted an excessive amount of attention to such philosophical questions as the nature of corporate personality and the necessity of authority from the state in order to incorporate. ${ }^{11}$ Beyond these questions, the hard core of the course explored the traditional topics of corporate powers, the liability of a corporation for the tortious and criminal activities of its representatives (including the philosophical question whether vicarious liability should indeed be imposed upon the entity), and the consequences of de facto and de jure incorporation and of ultra vires action. ${ }^{12}$

In the real world, however, no such simple picture existed. To a great extent the shareholders' rights had been altered by contractual provisions in the certificate of incorporation or bylaws. Under the "write-your-own-ticket" statutes, corporate purpose clauses customarily were stated in such broad terms as to permit the corporation to engage in almost any business under the sun, thus rendering meaningless any talk of ultra vires. It was customary to insert immunizing clauses in the certificate of incorporation in an effort to do away with judge-made fiduciary rules regulating the dealings between the corporation and its officers, directors and controlling shareholders. Preferred stock customarily carried no vote or had only a partial or contingent right to vote; holders of bonds or debentures might or might not have a right to vote.

When the holding company was sanctioned, control became further concentrated within the control group through use of partly or wholly-owned subsidiary corporations and holding company pyramids. It also became possible to achieve a further insulation from liability through the use of subsidiary corporations and in many situations to avoid service of process on the parent.

Furthermore, outside of the corporate voting systems, the devices of the voting trust and pooling agreements were available to concentrate control within particular blocs so as further to distort the voting system. Or, actual control of the corporation might take the form of a "shadow government" in which the officers or directors were mere puppets who like the ventriloquist's dummy appeared to speak for the corporation and the shareholders, but who in fact echoed the wishes of some invisible puppeteer. Such arrangements overrode the dogma prescribed in most corporation statutes that "the man-

11. See Canfield \& Wormser, Cases on Private Corporations (2d ed. 1925); Richards, Cases on Corporations (2d ed. 1924); Warren, Cases (2d ed. 1916).

12. Cf. Ripley, Book Review, 31 Colun. L. Rev. 1220 (1931) ; Rtpley, Matn Street and Wall Street (3d ed. 1929); Isaacs, Book Review, 41 Yale I.J. 150 (1931). 
agement of the corporation shall be vested in a board of directors elected by the shareholders." At best, the law school image gave a distorted picture of the corporate system in operation; at worst, it tended to obscure the social and economic role which the corporation had come to play in the American business system and the need for social controls in the public interest. It had long been clear to the corporate bar that law school courses in corporations were far removed from reality. ${ }^{13}$ Evidently, Douglas and Shanks decided to do something about it.

They did not march alone. Within the law school world, and particularly at Yale and Columbia, the law school curriculum and methods of legal education had come under sharp attack from a number of young Turks, with support by some of their seniors. ${ }^{14}$ This unrest was soon to erupt into a demand for legal "realism" in the study of law and legal institutions and for greater experimentation with new approaches to legal education. ${ }^{15}$ Professor Douglas was caught up in this ferment. The deficiencies of the conventional methods of teaching Business Associations and the call for a new approach was presented in a paper he read to the round table on Business Associations at the annual meeting of the American Association of Law Schools in December, 1928:

The focal point of study being the form of business unit . . . Thas resulted in the] analysis [becoming so] conceptualized that the attention is too frequently focused on the device used rather than on the function which the device is intended to perform. Though courts and lawyers and students have come closer than ever during the last twenty-five years to an analytical consideration of the social and economic forces working in and through the guise of legal concepts and labels the continued use of the old categories and classifications tends to confuse thought. . . . So long as the quest is for the economic and social forces involved in the cases it would seem that a set of categories which would focus attention on such forces would be more desirable. . . 16

13. Cf. Swaine, Book Review, 32 Colum. L. Rev. 402 (1932).

14. At the Columbia Law School, one of the leaders of this revolt against the school of analytical jurisprudence was Professor Underhill Moore. During his last two years in law school Mr. Justice Douglas did work with Moore on the relation of law and business and appears to have been greatly influenced by this association. Lerner, Wall Strct's New Mentor, 145 Natron 429,430 (Oct. 23, 1937).

15. This is not the place to do more than recall this controversy, which livened the Law Reviews for a time. Dean Pound, representing what might be called the "Old Guard," mounted a vigorous attack upon the leaders of this movement, whom he described as the "on-coming generation of American law teachers" and "our younger teachers of law." Pound, The Call for a Realist Jurisprudence, 44 HaRv. L. REv. 697 (1931). Professor K. N. Llewellyn's reply makes a point by point rebuttal of Dean Pound's bill of particulars; it also includes a bibliography of writings of the "realists," which may be of interest to later generations who may be unaware of this disputation. Llewellyn, Some Realism About Realism-Responding to Dean Pound, 44 Harv. L. Rev. 1222 (1931). Professor Douglas by this time had gained a place on Llewellyn's honor roll of the "new fermenters" in legal education.

16. The paper was later published: Douglas, A Functional Approach to the Law of Business Associations, 23 ILL. L. REv. 673, 674-76 (1928). 
His proposal focused on "three basic processes concerned with the organization of business": 1 . the assembly of resources ; 2 . "control" of the enterprise; and 3. absorption of losses. The first concerned long-term financing through bonds, stock or partnership contributions. The second would ascertain who actually runs the business: "Titular management can be identified. But actual control is more ephemeral. Such being the business phenomena it would be more realistic to correlate the study of the law to the facts." 17 The third category would deal with the mechanisms involved in the performance of the function of allocation of losses: "Who shall suffer most; who least? The man giving his labor, the seller his coal, the stockholder his property, the bondholder his funds, have each contributed to the operation of the industrial unit. . . To what extent can each get out the value of that which he contributes? These are problems in allocation of loss."18

In actual execution there was a considerable revision of these ideas. After some experimentation at the Yale Law School four courses emerged. The conventional courses of Agency, Partnership and Corporations were revamped (with the inclusion of additional materials on finance and accounting) into Business Units I (Losses), Business Units II (Management), Business Units III (Finance) and Business Units IV (Reorganization). ${ }^{19}$ And in 1931-32 Douglas and Shanks published four course books presenting their ideas for a functional approach to Business Associations. ${ }^{20}$

The book on losses, liabilities and assets represented primarily a change of emphasis, rather than a change in content. There was, however, a comparative treatment of the various forms of legal organization, resulting in a shift from a stress on history to that of concentrating on current problems of law and business. The book on management dealt with the various legal devices for allocating control within the corporate structure. These included voting and nonvoting shares, voting trusts, pooling agreements, restrictions on transfer of shares, and the like. Another group of problems centered around the legal strength of the various interest groups, as, for example, the right of a minority to prevent a dissolution or to compel the declaration of a dividend. The remainder of the book dealt with formalities for exercising control, once the allocation had been determined. ${ }^{21}$

17. Id. at 678 .

18. Id. at 680 .

19. See subjects listed as being taught by Professor Douglas in Assoc. of Am. LAw Schools, Directory of TeAchers FOR 1929 at 31; 1930 at 34; 1931 at 37.

20. Douglas \& Shanks, Cases on Business Units-Losses, Liabilities, and Assets (1932); Cases on Business Units-Management (1931) ; Cases on Business Units-Finance (1931); and Cases on Corporate Reorganization (1931).

21. For an indictment of traditional texts and case books on corporations and an enthusiastic endorsement by a Business School professor, see Isaacs, Book Review, 41 YAIE L.J. 150 (1931) ("The book . . . seems . . . to represent the first effective introduction of ... [the] modern aspects of corporation law into the law school curriculum."). Id. 150-51. And see O'Keeffe, Book Review, 5 So. CaL. L. Rev. 176 (1931). 
It was the books on finance and on reorganizations which made the greatest break with tradition. The former introduced entirely new material grouped around three aspects of the financing process: (1) the various types of securities and their provisions, ${ }^{22}$ (2) the methods of acquiring assets; ${ }^{23}$ and (3) the marketing of securities. ${ }^{24}$ And for the first time a case book included a generous number of corporate documents and forms illustrating the instruments of finance then in current use, including a corporate mortgage and a debenture as well as exemplary forms illustrating the various types of preferred and common stocks. ${ }^{25}$

The book on corporate reorganizations was the first in its field. It was concerned with the process of refinancing corporations in financial stress through the use of the equity receivership, or through voluntary procedures without resort to court processes. In the main, emphasis was placed upon "the legal problems incident to the preparation, promulgation, and consummation of the reorganization plan and agreement."26

The overall purpose of this new approach was to revitalize the study of corporate law by broadening it to include related materials in the fields of business and finance. This meant a shift away from "teaching teachers' law" to "teaching lawyers' law."27 Professor Douglas recognized that these case books were only a beginning; that the material with which the financial lawyer constantly deals "consists of statistics, banking practices, finance, accounting principles and practices, problems of securities distribution, problems of securities exchanges, problems of marketing, of prices, of labor, of production, etc."28 Aside from an occasional reference to Dewing, ${ }^{29}$ Veblen, ${ }^{30}$ Brandeis, ${ }^{31}$ and Ripley, ${ }^{32}$ however, only a minimum amount of business materials as such

22. These included materials for the study of the corporate mortgage and debenture and preferred and common stocks.

23. Among the nonconventional topics considered were those of acquisitions of businesses through the use of option agreements, sales of assets and merger and consolidation. Attention was given to the antitrust and tax aspects as well as to rights of appraisal.

24. Here again such nonconventional areas as Blue Sky laws, selling circulars or prospectuses, stock exchange listing and taxation were dealt with.

25. The book on finance was given an enthusiastic review by Mr. Elihu Root, Jr. in 41 YaLE L.J. 481 (1932) and a rather cool reception in Payne, Book Review, 18 VA. L. REV. 593 (1932).

26. The novelty of a case book on corporate reorganizations generated a number of reviews commenting upon the usefulness of the book for corporate lawyers as well as for teaching purposes. Of most interest to the writer were those of Dodd, 17 CoRNELL L.Q. 317 (1932) ; Dewing, 45 Harv. L. Rev. 1138 (1932); Kline, 41 Yale L.J. 1255 (1932); Peppin, 20 Calif. L. Rev. 347 (1932); and Swaine, 32 Colum. L. Rev. 402 (1932).

27. Douglas, Education for the Law, An Address on law teaching in America before the American Association of Collegiate Schools of Business in April, 1936, printed in Douglas, Democracy and Finance 278 (Allen ed. 1940).

28. Id. at 287.

29. Dewing, Financtal Policy of Corporations (4th ed. 1934).

30. Veblen, Absentee OWNership and Business Enterprise (1923).

31. Brandeis, Other People's Money (3d ed. 1932).

32. Ripley, Main Street and Wall Street (2d ed. 1927). 
was included. In this respect the materials were like an unfinished symphony; there seems little doubt that Douglas envisaged a long range project looking toward a full integration and fusion of business and legal materials for the study of the corporation as a business institution. He referred to this uncompleted task in 1936 when evaluating the existing deficiencies in American legal education, particularly in the business field:

[We] are probably seeing only the bare beginning of an endeavor to study the social and economic phenomena of our times.

. . . The impact of the corporate device on our social and economic life is almost wholly neglected. The corporation as an object of control and as a method of control is passed by. Even the nonconformists have only started on the task of broadening the horizon in the corporate field.

The upshot . . . is not merely that adequate treatment of the law of corporation finance calls for use of so-called business materials. The point is that any considered treatment of this subject would entail a subtle fusion of the so-called legal and business aspects since in final analysis they are one. As a practical matter, viewed either from the legal or business point of view, it would be difficult, except in terms of emphasis, to differentiate between a law course and a business course on corporation finance. ${ }^{33}$

But Professor Douglas did not conceive the law school mission as being merely that of training more efficient corporate technicians. It was a matter of producing socially enlightened lawyers. ${ }^{34}$ Although there are today far richer materials in the fields of business and finance than existed in the twenties and thirties, it must be confessed that legal education in most fields still fails to measure up to these objectives. Through a broadened training in accounting, finance and securities regulation and various seminars in business planning we may indeed turn out better technicians. One wonders, however, whether in our efforts to teach technical proficiency we also achieve the equally important objective of challenging our students to appraise the effectiveness of our existing system of corporate regulation at the state and federal levels and to weigh what steps might be taken to make the system more responsive to community needs without hamstringing legitimate business. The recent Report of the Special Study of the Securities Market ${ }^{35}$ makes just such an appraisal of the operation of our securities markets and the overall effectiveness of the SEC legislation. Surely, if the law school is to fulfill its true role in the education of the bar, the broader aims envisaged by Professor Douglas must be made a dominant objective of legal education.

Quite apart from this successful effort to revitalize legal training in the fields of law and finance, the half dozen years at the Yale Law School (1928-34) were enormously productive in terms of legal research. This research, much of which was done in collaboration with social scientists and other scholars in

33. Douglas, op. cit. supra note 27 , at 281-84.

34. Id. at 286.

35. SEC, Report of Special Study of Securities Markets, H.R. Doc. No. 95, 88th Cong., 1st Sess. (1903) [hereinafter cited as SEC Specral Study]. 
related fields, focused continuously on an attempt "to relate the legal problem to its economic and social environment."

The end products which found their way into the law reviews are astonishing in both quality and quantity. They started off with the brillant study of vicarious liability in terms of risk administration: liability should be imposed vicariously upon that person who most nearly fills the role of the entrepreneur in a given situation and thus possesses the ability to administer the risk through manipulation of profit or cost differentals. ${ }^{36}$ The increasing use of a parentsubsidiary corporate structure evoked a somewhat similar analysis of the methods of organization and operation of subsidiaries which should be regarded as essential to secure parental insulation from liability for the subsidiary's debts, again in terms of loss allocation. ${ }^{37}$ The gap between ownership and control in the modern corporation, arising from the diffusion of shares among scattered shareholders accompanied by some shocking disclosures of management derelictions, touched off a provocative article concerning "Directors Who Do Not Direct." Several proposals were made for strengthening the position of the shareholder vis-à-vis management within the corporate structure. Among these was a suggestion for financing and developing a shareholders' protective association, a nonprofit corporation to act as caretaker for shareholders' interests. ${ }^{38}$

At or just prior to the 1929 stock market debacle, Professor Douglas had joined forces with the Yale Institute of Human Relations to conduct a study of the antecedents of business failures in cooperation with the United States Department of Commerce and Judge William Clark, sitting in bankruptcy in the Federal Court for the District of New Jersey. This early experiment in research in the behavioral sciences generated two articles exploring problems and techniques in social science investigations ${ }^{39}$ and others summarizing some of the causes of business failures together with recommendations for improvement of the bankruptcy act and its administration. ${ }^{40}$

36. Douglas, Vicarions Liability and Administration of Risk: $I$ \& $I I, 38$ YaLE L.J. 584,720 (1929). This is not to say that this effort to apply the "scientific method" to the difficult problem of vicarious liability was entirely successful. Indeed, Professor Douglas admitted that the "earmarks" of the entrepreneurial test (control, ownership, losses, and profits) were helpful in the preliminary stages, but that in the final analysis the "prublem would take on a sociological aspect" to be weighed in terms of risk prevention and risk: distribution. Id. at 597 n.35.

37. Douglas (with Shanks), Insulation. From Liability Through Subsidiary Corporations, 39 Y ALE L.J. 193 (1929). Cf. Anderson v. Abbott, infra note 282.

38. Douglas, Directors Who Do Not Direct, 47 Harv. L. Rev. 1305 (1934).

39. Douglas (with Clark and Thomas), The Business Failures Project-A Problcm in Methodology, 39 YALE L.J. 1013 (1930); Douglas (with Thomas), The Business Failures Project-II. An Analysis of Methods of Investigation, 40 YALE L.J. 1034 (1931).

40. Douglas (with Marshall), A Factual Study of Bankruptcy Administration and Some Suggestions, 32 Colum. L. Rev. 25 (1932); Douglas, Some Functional Aspects of Bankruptcy, 41 YaLe L.J. 329 (1932); Douglas, Wage Earner Bankruptcies-State vs. Federal Control, 42 Yale L.J. 591 (1933). Professor Douglas also sponsored two interesting studies by students in the Yale Law School as adjuncts of the bankruptcy 
As the drive for Federal securities regulation got underway, Professor Douglas began to concentrate more and more on various problems of securities distribution. In 1932-33, he teamed up with Professor George E. Bates of the Harvard Business School on a series of articles on various aspects of securities regulation. Two of those surveyed a wide range of problems surrounding the secondary distribution of securities by brokers and dealers; the fiduciary relationship between broker and customer and dealer and customer; an examination of various business arrangements in which the broker or dealer acquires an interest adverse to his customer; and the legal duties flowing from these relationships. ${ }^{41}$

Messrs. Douglas and Bates were highly critical of the customary practice in which a broker assumed the role of a security merchant in the purchase of a security for a customer without disclosing that he was dealing for his own account. The theory advocated, in contrast with some judicial decisions, would impose a fiduciary duty upon the broker to disclose fully the capacity in which he acted, the price paid for the security, and any commissions received in connection with the purchase. The views thus urged were essentially those later adopted by the Securities and Exchange Commission in the interpretation and administration of the general antifraud provisions of the Securities Act of 1933 and of the Securities Exchange Act of $1934 .{ }^{42}$

Upon the adoption of the Securities Act of 1933 numerous problems of statutory construction and of administration were widely discussed, the question being raised whether the Act had not created so many uncertainties and impediments for the business community as to be an unhealthy deterrent to a lagging new issue market. Joining the dialogue, Douglas and Bates dissected the Act, pointed up some of its deficiencies, ambiguities and uncertainties; and recommended that the Act "be amended promptly not so as to change its fundamental principles but in order to make it unambiguous, clear, and consistent."43 Furthermore, it was recommended that administration of the Act, then in the Federal Trade Commission, should be vested in an effective specialized independent agency with a broader legislative base and with a "more pervasive and flexible power" to deal with additional regulatory problems in the field of finance which the authors envisaged as in need of unique treatment. ${ }^{44}$

project: Fortas, Wage Assignments in Chicago-State Street Furniture Co. v. Armour \& Co., 42 Yale L.J. 526 (1933), and Nehemkis, The Boston Poor Debtor Court-A Study ir Collection Procedure, 42 Yale L.J. 561 (1933).

41. Douglas (with Bates), Secondary Distributions of Securities-Problems Suggested by Kinney v. Glenny, 41 YaLE L.J. 949 (1932); Douglas (with Bates), Stock "Brokers" as Agents and Dealers, 43 Y ALE L.J. 46 (1933).

42. Arleen W. Hughes, 27 S.E.C. 629, 952 (1948), aff'd, 174 F.2d 969 (D.C. Cir. 1949); Note, 57 Yale L.J. 1316 (1948); 3 Loss, Securities Regulation 1500-08 (2d ed. 1961).

43. Douglas (with Bates), The Federal Securities Act of 1933, 43 YaLE L.J. 171, 211 (1933) ; Douglas (with Bates), Some Effects of the Secturities Act Upon Investment Banking, 1 U. CHI. L. REv. 283 (1933).

44. Douglas (with Bates), supra note 43 at 43 YALE L.J. 171, 216-17 (1933). 
Shortly thereafter, however, Professor Douglas expressed his conviction that the Securities Act standing alone would not be able to cope with the difficult problem of protecting investors. ${ }^{45}$ This view rested upon three propositions which seemed to him to be tolerably clear. First, the Securities Act fell far short of accomplishing its purpose. Second, in any genuine program for the permanent correction of the evils of high finance, the Securities Act was of a secondary character. Third, vigorous enforcement of the Act would spell its own defeat, for it was essentially antithetical to our whole economy. It was, he believed, "a nineteenth-century piece of legislation . . . [an attempt to] 'turn back the clock' to simpler days." is composed of little business units seeking funds and people who are "buying shares with the modicum of intelligence with which they are supposed to buy wearing apparel or horses." 47 It assumes that the details of a large business enterprise can readily be stated in a registration statement in a form that persons lacking training or intelligence in financial matters can understand. It imposes liability upon directors of all companies, large or small, whether or not the directors can possibly make a reasonable investigation of the accuracy of the registration statement. And in actual operation, though perhaps the Act will prevent some fraudulent transactions which cannot stand the light of publicity, essentially investors are still without any real protection.

Furthermore, the Act merely requires a disclosure at the time the security is first marketed. The effect will soon be lost by the passage of time. There is no machinery for making available to investors periodic reliable financial data and other information concerning issuers. Nothing in the Act purports to control the power of the self-perpetuating management group which dominates most corporations. Nothing attempts to deal with the protection of the rights of minorities; with the problem of capital structure, its soundness or unsoundness; with mobilizing the flow of capital. Any really comprehensive program for social control of finance must

... envisage a wide-range - from the increments of profit and control (which are incident to the constitution and form of the organization) to the terms and conditions of the organization, the kind and amount of securities which may be issued, the terms on which they may be issued, and the person to whom they may be sold. ... The control needed is one which would combine regulation by industry with supervision by government. 48

If this form of regulation could be coupled with control of the stock exchanges and "if more effective supervision over corporate organization and reorganization and over the relation of investors to the management were provided by federal incorporation or otherwise, we should have laid such solid bases for protection of investors as to make the ... [Securities] act become wholly

45. Douglas, Protecting the Investor, 23 Yale Review (n.s.) 521 (1934).

46. Id. at 529 .

47. Ibid.

48. Id. at 530-32. 
insignificant." ${ }^{49}$ In the following year, with the adoption of the Securities Exchange Act of 1934, Federal control of the securities markets moved in this direction and subsequent SEC Acts became more pervasive in character, though falling short of the degree of control which apparently Douglas foresaw.

The machinery developed for the reorganization of financially embarrassed corporations was in critical need of overhaul in 1933. More than fifty railroads owning in excess of twenty thousand miles of track were then in receivership; other railroads had millions of outstanding debt securities with impending maturities and a seeming lack of capacity to pay; and the market for new issues for the purpose of refunding issues soon to become due was stagnant.50 Many industrial corporations were also in deep financial trouble. Over the years the reorganization machinery had counted upon the availability of the equity consent or "umbrella" receivership. ${ }^{51}$ This institution, a construct of ingenious lawyers, when stripped of all of its mythology, revealed a sordid picture of champerty, conflicts of interest, abuse of process, and other violations of professional ethics participated in by respectable members of the reorganization bar. In any realistic sense their conduct, though tolerated, was no less antisocial than that of the "ambulance chaser" or the "striker." 2 Aware that federal court processes were being abused, the United States Supreme Court, after a series of warnings, ${ }^{53}$ emphatically advised the reorganization bar that the federal equity receivership was not a proper vehicle for effecting a corporate reorganization, except in the case of "railroads and other public utilities where continued operation of the property and preservation of its unity seemed to be required in the public interest."

At the same time, however, the bankruptcy court was not an acceptable forum for effecting a corporate reorganization. As early as 1916, Paul D.

49. Id. at 533 .

50. See Moody, Ratrroads at a18 (1932), as supplemented by Moody, MaNUal For StEAn RaIlroads 866 (1932); 46 ICC ANN. Rep. 15-16 (1932); Swaine, Corporate Reorganization Under the Federal Bankruptcy Power, 19 VA. L. Rev. 317 (1933).

51. On the history and evolution of the equity consent receivership, see 2 SwaINE 167-97; Cravath, The Reorganization of Corporations, in Some Legal Phases of CoRporate Financing, Rrorganization and Rggulation 153 (1917); Byrne, The Foreclosure of Railroad Mortgages in the United States Courts, id. at 77, and Swaine, Reorganization of Corporations: Certain Developments of the Last Decade: I, 27 CoLUM. L. REv. 901 (1927), id. II, 28 CoLUM. L. REv. 29 (1928).

52. This is not to suggest that reorganization lawyers regarded customary reorganization practices as reprehensible. They regarded their conduct as fully justified to protect the interests of the security holders. For the best analyses of fact and fiction, see Foster, Book Review, 43 Yale L.J. 352, 355-56 (1933); Lowenthal, The Investor Pays 131-45 (1933); ARNold, The FolkLoRe of CApItalisM ch. 10 (1937).

53. See Harkin v. Brundage, 276 U.S. 36, 52 (1928); Michigan v. Michigan Trust Co., 286 U.S. 334, 345 (1932).

54. First Nat. Bank v. Flershem, 290 U.S. 504, 515 (1934). And see Shapiro v. Wilgus, 287 U.S. 348, 355-56 (1932). For a more sympathetic and nostalgic view of the equity consent receivership by one who was piqued by the Supreme Court's hostility, see Friendly, Some Comments on the Corporate Reorganizations Act, 48 HARV. L. REv. 39, 41-45 (1934). 
Cravath had noted the "impatience of the bankruptcy court to secure an early sale and distribution"55 whereas the equity receivership might permit the debtor to continue in possession of the properties while sitting "under the protection of the Chancellor's umbrella," thereby staving off creditors while hoping to ride out the financial storm. Furthermore, doubts were expressed as to the jurisdiction of the bankruptcy court to pass on the fairness of any reorganization. In the absence of any such power, Northern Pacific Ry. $v$. Boyd ${ }^{56}$ was thought to stand for the proposition that the purchasing corporation must, as a part of the plan of reorganization and sale of the properties, make a "fair offer" to an undetermined number of claimants, if the shareholders retained an interest in the corporation over and above any fresh money contributed by them to the new enterprise. ${ }^{57}$ The deepening financial crisis and the need for new reorganization processes impelled the Congress in 1933 and 1934 to amend the Bankruptcy Act to regulate reorganizations of railroad companies and other general business corporations. ${ }^{58}$

In the midst of this ferment and as a part of his broad examination of bankruptcy problems, Professor Douglas explored some of these pressing problems. There were, for example, large chain store organizations, which, as lessees, had become committed on long-term leases calling for the payment of fixed rents on store locations only later to face declining sales and inventory losses arising from depressed prices. These tenants began to turn to bankruptcy (or receivership) as a means of avoiding leases and cutting overhead. In an article, written with Jerome (later Judge) Frank, then a research associate in the Yale Law School, Professor Douglas took a long look at the landlord's claim in bankruptcy or in equity receivership, from the standpoint of provability of the claim and as respects the application of the Boyd case.50 The Boyd case was thought to open the way for the landlord to participate in the reorganization on an equitable basis even though at the time of the reorganization sale his claim was wholly contingent. ${ }^{60}$

The pages of the Harvard Law Review were used in February, 1934, to take a close look at the utility of protective committees in railroad reorganiza-

55. Cravath, The Reorganization of Corporations, in Some Legal PHASES of CoRporate Financing, Reorganization and Regulation 153, 161 (1917).

56. 228 U.S. 482 (1913).

57. See Friendly, supra note 54 , at $47-48$.

58. The Railroad Reorganization Act, 47 Stat. 1467, 11 U.S.C.A. $\$ 205$ (1953) added $\S 77$ to the Bankruptcy Act. This was followed in 1934 by the so-called Corporate Reorganizations Act, 48 Stat. 911 (1934), which added $\$ 77 \mathrm{~A}$ and $\$ 77 \mathrm{~B}$. Section 77A conferred upon the courts of bankruptcy jurisdiction over corporate reorganizations of railroad corporations, except those subject to the provisions of $\$ 77$, and also any other corporation which could become bankrupt. For general comment, see Dodd, Reorganizations Throngh Bankruptcy: A Remedy for What?, 48 HARv. L. Rev. 1100 (1935) ; Friendly, supra note 54; Weiner, Corporate Reorganization: Section $77 B$ of the Bankruptcy Act, 34 Colum. L. Rev. 1173 (1934).

59. See note 56 supra.

60. Douglas \& Frank, Landlords' Claims in Reorganizations, 42 YAIE L.J. 1003 (1933). 
tions in view of the enactment of Section 77 of the Bankruptcy Act. ${ }^{61}$ This article sought to answer specific criticisms of the "constitution, functions, and control of protective committees" which had recently been made by Max Lowenthal. ${ }^{62}$ It was Mr. Lowenthal's thesis that the system and new legislation were defective because: (1) the methods for constituting protective committees and the broad terms of the deposit agreement effectively deprived the security holders of any voice in formulating the plan of reorganization; (2) the security holders' ratification of the plan of reorganization was thus wholly fictitious; (3) adequate protection of the small investors should not depend upon the representation of large institutional investors who are too closely tied to the banking and speculative equity groups; (4) protective committee racketeering was not only still possible, but even probable under the new legislation; (5) fees and expenses remained largely uncontrolled; and (6) committee members and their associates were not specifically prohibited from trading in the deposited securities and were thus in a position to profit from the use of inside information, not generally available to security holders.

Professor Douglas conceded the need for reform and regulation of protective committees but rejected the solutions proposed by Mr. Lowenthal. In general, he thought that there was "great utility and virtue in having independent, well organized, aggressive, powerful protective committees"; that the bargain in reorganization could not be struck by the use of a town meeting; that the committee had to be delegated broad powers to act when it went into the bargaining sessions with other creditors; and that the solution lay in perfecting the machinery for the selection of committees and in minimizing in various ways the possibilities of abuse. Indeed, most of the abuses had arisen in the past "because so often the committees [had] ... been constituted by the inside groups ... drawn from the old management or the financial interests associated with it. . . " or were composed of "speculative equity groups." ${ }^{33}$ The solution lay in applying the principles of representative democracy to the selection process: (1) election machinery should be provided to enable private interests to "select their own representatives to serve their cause"; 04 (2) the selection process "would entail full disclosure of the various interests and affiliations of those being elected"; 65 (3) the committees so constituted should have "a broad grant of powers so that they would have real authority necessary to serve investors effectively"; 66 (4) the Interstate Commerce Commission should be given the power "to adjudicate differences between depositors and committees as to certain matters, such as expenses." ${ }^{\text {"67 }}$

61. Douglas, Protective Committees in Railroad Reorganizations, 47 HARv. L. REv. 565 (1934).

62. Lowenthal, The Investor Pays (1933) ; Lowenthal, The Railroad Reorganization Act, 47 HARv. L. Rev. 18 (1933).

63. Douglas, supra note 61 , at $566-67$.

64. Id. at 587.

65. Ibid.

66. Id. at 588 .

67. Ibid. 
A few months later Congress, in enacting the Securities Exchange Act of 1934, "authorized and directed" the Securities and Exchange Commission "to make a study and investigation of the work, activities, personnel and functions of protective and reorganization committees . . . to report the result of its studies and investigations and its recommendations to the Congress" by January, $1936 .{ }^{68}$ It is probable that it was the Harvard Law Review article on protective committees "which took the eye of [Chairman Joseph P.] Kennedy and [Commissioner James M.] Landis ...". and which led to the appointment of Professor Douglas as the Director of the SEC Protective Committee Study in 1934.69 With this event his relatively brief but astoundingly successful career as professor of law came to an end and the five years of government service began. According to Time, "When Bob Hutchins became president of University of Chicago, [in 1929] he dubbed Douglas 'the outstanding professor of law of the nation,' offered him $\$ 20,000$ to go to Chicago."70 Nothing in Professor Douglas' record of achievement at Yale suggests that President Hutchins was exaggerating.

\section{THE SEC YEARS}

The Douglas record at the Securities and Exchange Commission was well publicized at the time. ${ }^{71}$ His more notable public addresses and statements, sketching his philosophy of corporate and securities regulation, have been collected and published in the well-known book, Democracy and Finance. ${ }^{72}$ The book's timely appearance, shortly after his appointment to the highest court, has made it of continuing interest not only to students of corporation finance but to all who have sought insights into the Justice's attitude both to the government of business and to the business of government. On the more technical side there is the now classic Protective Committee Study ${ }^{\mathbf{7 3}}$ which he prepared with the assistance of an extraordinarily capable staff. This study laid the foundation for essential legislative reforms: the Chandler Act which added Chapter $\mathrm{X}$ to the Bankruptcy Act ${ }^{74}$ and the Trust Indenture Act of 1939.75 Other securities legislation is directly traceable to his brilliant leadership on the Commission. Perhaps the most noteworthy is the Maloney Act ${ }^{76}$

68. Securities Act of 1933, $\S 28$ added by Title II, of the Securities Exchange Act of 1934, 48 Stat. 909 (1934).

69. Time, Oct. 11, 1937, p. 64.

70. Ibid.

71. Among the best character studies are Rodell, Donglas Over the Stock Exchange, Fortune, Feb. 1938, p. 64; Lerner, Wall Street's New Mentor, Nation, Oct. 23, 1937, p. 429; and Creel, Young Man Went East, Collier's, May 9, 1936.

72. Douglas, Democracy and Finance (1940 ed.), with an introduction and notes, by James Allen of the SEC staff.

73. SEC, Report on the Study and Investigation of the Work, Activities, Personnel and Functions of Protective and Reorganization Connmttees (1936-40) [hereinafter cited as SEC REPORT].

74. Sections 101-276, 52 Stat. 840, 883 (1938), 11 U.S.C. \$§ 501-676 (1958).

75. 53 Stat. 1149 (1939), 15 U.S.C. § 77aaa (1958).

76. 52 Stat. 1070 (1938), adding § 15A, 15 U.S.C. $\S \S 780-83$ (1958). 
which furnishes the legislative base for the National Association of Securities Dealers. The investment company study and legislation was in the works and well along when Douglas left the Commission for the Court. All of this legislation stands as an enduring monument to the Douglas era of the SEC.

Looking backward after a quarter century at his accomplishments while with the Commission, the most notable contributions seem to me to lie in three directions: (a) the effort to overhaul corporate reorganization practices; (b) the battle for stock exchange reforms; and (c) the extension of the principle of self-regulation to the over-the-counter markets through the mechanism of the National Association of Securities Dealers (NASD).

\section{A. The Experiment in Reorganization Reform}

Reference has already been made to the grimy state into which reorganization practices had fallen in the pre-depression period. ${ }^{77}$ When the great depression swept across the country, bringing with it an enormous increase in the number of financially distressed concerns, the reorganization machinery came more and more into the limelight; and the story of its abuse became a matter of common knowledge and concern. Concurrently with the adoption of section 77B of the Bankruptcy Act in 1934, Congress directed the Securities and Exchange Commission to undertake a study of creditors' and stockholders' protective committees in reorganizations. ${ }^{78}$ The aim of the protective committee study was to investigate reorganization practices, expose them to public view, and make recommendations to the Congress. The report was presented to Congress during the period April 30, 1936 to September 30, 1940, in eight parts. ${ }^{79}$

By 1937, the Commission had completed those parts of the report most directly concerned with reorganization procedures. The report delved into reorganization practices in far greater depth than any previous study or investigation; nevertheless, as one knowledgeable commentator observed: "The factual portions of the Report disclose little that students of reorganization have not generally known, and reorganizers taken for granted." 80

The Study found that too often reorganizations were masterminded from behind the scenes by reorganization managers allied with the corporation's management or its bankers. ${ }^{81}$ Control was cemented by shopping for a "friend-

77. See text accompanying note 52 supra.

78. Securities Exchange Act of 1934, $\$ 211,48$ Stat. 881, 909 (1934), amending the Securities Act of 1933.

79. For critiques of the Report, see Dodd, The Securities and Exchange Commission's Reform Program for Bankruptcy Reorganization, 38 CoLuM. L. REv. 223 (1938); Swaine, "Democratization" of Corporate Reorganizations, 38 CoLUMr. L. REv. 256 (1938); Weiner, The Securities and Exchange Commission and Corporate Reorganization, 38 Colum. L. Rev. 280 (1938); Laporte, Changes in Corporate Reorganization Procedure Proposed by the Chandler and Lea Bills, 51 HARv. L. REv. 672 (1938).

80. Weiner, supra note 79 , at 280.

81. The Study found that in $67 \%$ of the cases arising under $\$ 77 \mathrm{~B}$ in 1936 , the property had been remitted to the custody of the debtor. SEC REPORT, pt. II, at 523 n.4. 
ly" judge willing to leave the debtor in possession and to appoint "friendly" trustees. ${ }^{82}$ This brotherly approach was likely also to permit the inside group to ward off investigations of fraud, mismanagement or other irregularities which may have contributed to the debacle. ${ }^{83}$ Armed with this advantage and a private list of creditors and shareholders, consents were solicited under deposit agreements which forestalled the organization of an effective opposition, ${ }^{84}$ permitted the insiders to trade in the securities on the basis of inside information, ${ }^{85}$ and gave to the managers untrammeled power to fix the expenses of reorganization, including attorneys' fees, free of judicial supervision. ${ }^{80}$ With a plan of reorganization prepared in advance by the lawyers for the Committee and the necessary consents in hand, courts generally could be prevailed upon to confirm the plan against attacks of unfairness on the theory that the creditors and shareholders had freely consented and were in the best position to protect their own interests. ${ }^{87}$ The whole affair thus became a "lawless" operation masquerading under a facade of legitimacy. The larger question was whether the machinery of government was capable of making any lasting and effective reforms in this traditionally chaotic field.

The Commission recommendations for reform fell into three broad categories: ${ }^{88}$ (a) alteration of the reorganization provisions of section $77 \mathrm{~B}$ of the Bankruptcy Act; (b) providing additional investor protection for holders of debt securities issued under Trust indentures; and (c) direct regulation of the structure and activities of protective committees in reorganizations. These proposals were incorporated into three bills: the Chandler Act ${ }^{83}$ to add Chapter X to the Bankruptcy Act, the Barkley Bill ${ }^{90}$ containing the Trust Indenture Act and the Lea Bill, ${ }^{91}$ the so-called Protective Committee Act.

The revisions of reorganization procedure, with some modifications, ultimately were adopted as Chapter X of the Bankruptcy Act, superseding Section

For the techniques used by inside groups to capture and maintain control over the proceedings, see SEC REPORT, pt. I, at 243-670.

82. SEC REPORT, pt. I, at 243-312.

83. Various case histories were reported to substantiate the proposition that claims against prior management will not be vigorously pursued if the receivers and trustees, and the protective committees, are dominated by management and allied interests. SEC REPORT, pt. II, at 32-163, 187-200, 250-94.

84. SEC REPORT, pt. I, at 408-670.

85. SEC REPORT, pt. II, at 315-51. Fifty-seven per cent of all deposit agreements reviewed by the Commission expressly permitted trading in the securities represented by the committees on which the insider served; only 4 out of 846 agreements expressly prohibited or restricted such trading. $I d$. at 319.

86. SEC REPORT, pt. II, at 351-94.

87. H.R. Rep. No. 1409, 75th Cong., 1st Sess. 38 (1937) ; Douglas, Democracy and FinaNCe 189 (Allen ed. 1940).

88. For the Commission's conclusions and recommendations see SEC Reporr, pt. VIII at 308-43.

89. H.R 6439, 75th Cong., 1st Sess. (1937).

90. S. 2344, 75th Cong., 1st Sess. (1937).

91. H.R. 6968, 75th Cong., 1st Sess. (1937). 
77B. ${ }^{92}$ The new requirement of a qualified, independent and disinterested trustee (except in certain cases involving small companies) ${ }^{93}$ helped to restore the integrity of the reorganization process, and to break the grip which reorganization managers and bankers had previously held over the rehabilitation of insolvent companies. ${ }^{94}$ The trustee is granted broad responsibilities in effecting the reorganization of the enterprise. Thus, if the court approves, he may investigate the condition of the company and the causes of failure, ferret out fraud or mismanagement giving rise to corporate claims, and dismiss the management or retain them to operate the business under his supervision. ${ }^{95}$ $\mathrm{He}$ is further charged with the duty of formulating a plan of reorganization, after consultation with creditors and shareholders. ${ }^{96}$

For the expertise formerly furnished by reorganization managers who often were identified with the debtor, or its bankers, the SEC is substituted. The court may submit to the Commission any plan which it regards as worthy of consideration for its examination and report and must do so in those cases where the scheduled indebtedness exceeds $\$ 3,000,000 .^{97}$ Although the Commission's report is purely advisory, the Commission is in a position to play a crucial and aggressive role in the reorganization process. ${ }^{98}$

After formulaton of the plan by the trustee and the submission by the SEC of its advisory report, the Court must tentatively approve the plan before its submission to creditors and shareholders. ${ }^{99}$ Every effort is made to

92. 52 Stat. 840, 883 (1938), 11 U.S.C. $\$ 501-676$ (1958).

93. Section 156, 52 Stat. 888 (1938), 11 U.S.C. $\$ 556$ (1958). In the view of Commissioner Douglas "... the independent trustee is the real key to reform. In comparison, the other reforms are secondary." Hearings on H.R. 6439, supra note 92, at 177. The same standards of independence required of trustees are also made applicable to counsel to the trustee. Section 157, 52 Stat. 888 (1938), 11 U.S.C. $\$ 557$ (1958). A "disinterested" person is defined in $\$ 158,52$ Stat. 888 (1938), 11 U.S.C. $\$ 558$ (1958).

94. Control by these groups hinged upon the possibility of appointing "friendly" trustees and of leaving the debtor in possession. Section 128, 52 Stat. 886 (1938), 11 U.S.C. $\S 528$ (1958), rendered forum shopping virtually impossible by confining jurisdiction to the district where the principal place of business or principal assets are located rather than in the state of the debtor's incorporation.

95. Section 167, 52 Stat. 890 (1938), 11 U.S.C. $\$ 567(1)$ (1958). On the importance of an opportunity for a thorough appraisal of management on the occasion of a reorganization, see Douglas, Dearocracy and Finance 188-91 (Allen ed. 1940).

96. Sections 167 (b), 169, 52 Stat. 890 (1938), 11 U.S.C. $\$ \S 567($ b), 569 (1958).

97. Section 172, 52 Stat. $\$ 90$ (1938), 11 U.S.C. $\$ 572$ (1958). The SEC must be given notice of all steps taken in connection with the proceedings. 52 Stat. 903 (1938), as amended, 66 Stat. 431 (1952), 11 U.S.C. $\$ 665$ (1958). It may file an appearance in any such proceeding upon approval of the judge and thus attain the status of an interested party, with the right to be heard on all matters. But it is expressly denied the right of appeal. Section 208, 52 Stat. 894 (1938), 11 U.S.C. $\$ 608$ (1958).

98. See Douglas, Demrocracy and Finance 191-92 (Allen ed. 1940).

99. Section 174, 52 Stat. 891 (1938), 11 U.S.C. \$ 574 (1958). Inside groups are thus forestalled from attempting to gain control of the reorganization by using prior consents to corral creditors and shareholders. Indeed, unless the court permits prior solicitations, creditor consents accepted before such submission, even though merely provisional, are invalid. Section 176, 52 Stat. 891 (1938), 11 U.S.C. $\$ 576$ (1958). 
protect outside creditors and shareholders by making the court's approval conditional upon a finding that the plan is "fair and equitable, and feasible."100 Final confirmation is further contingent upon approval by two-thirds in amount of the creditors of each class, and, if the debtor is not found insolvent, by the shareholders holding a majority of each class of stock. ${ }^{101}$

Fees and expenses are subject to judicial control.102 Although monetary recognition is to be given to all those who contribute constructively to the reorganization, overall compensation for fees is thus to be kept within reasonable bounds. ${ }^{103}$ Various devices are introduced to discourage obstructionists ${ }^{104}$ or the intervention of purely speculative interests. ${ }^{105}$ Inside groups no longer are to be allowed to have a monopoly on private lists of bondholders. ${ }^{108}$

The Protective Committee Study's recommendations concerning corporate indentures and trustees ultimately triggered the Trust Indenture Act of 1939.107 This statute subjects trustees under trust indentures to disqualifica-

100. Section 174, 52 Stat. 891 (1938), 11 U.S.C. $\$ 574$ (1958). It was thought that with the administrative and expert financial assistance of the SEC the courts would be in a position to play a vital and affirmative role in reorganization. Douglas, Democracy AND Finance 194-96 (Allen ed. 1940).

101. Section 179, 52 Stat. 892 (1938), 11 U.S.C. $\$ 579$ (1958).

102. Prior to the enactment of Chapter $X$, fees of committees and their counsel were beyond the jurisdiction of the court, if made the subject of private agreement. This proposition was established in the famous St. Paul reorganization, where the Supreme Court held that the Interstate Commerce Commission lacked jurisdiction to control the fees of the protective committees and their counsel which had been fixed by an agreement between the committees and security holders to which the debtor railroad was not a party. United States v. Chicago, M., St. P. \& P. R.R., 282 U.S. 311 (1931).

103. Sections $241-50,52$ Stat. 900 (1938), 11 U.S.C. $\$ \S 641-50$ (1950). No compensation is to be allowed to "any committee or attorney, or other person acting in the proceedings in a representative or fiduciary capacity. . . " who after assuming this role purchases or sells the debtor's claims or stock, directly or indirectly, without approval of the court. Section 249, 52 Stat. 901 (1938), 11 U.S.C. \& 649 (1958).

104. Attorneys for creditors and stockholders who appear on any matter must file a statement containing the names and addresses of those whom they represent. Section 210, 52 Stat. 895 (1938), 11 U.S.C. $\$ 610$ (1958).

105. Every person or committee, representing twelve or more creditors or stockholders, and every indenture trustee must furnish the court a written statement, under oath, which includes (1) a copy of the instrument under which they are acting; (2) the facts in connection with their selection; (3) the amounts of claims or stock owned; (4) the dates of acquisition, prices paid and amounts thereafter sold; and (5) a statement that such claims or stock were acquired at least a year before the filing of the petition. Section. 211, 52 Stat. 895 (1938), 11 U.S.C. \& 611 (1958).

106. The court may now order any person having a list of security holders to turn this information over to the trustee if it regards this information as necessary for the preparation of the list of creditors. Section 165, 52 Stat. 889 (1938), 11 U.S.C. $\$ 565$ (1958).

107. 53 Stat. 1149 (1939), 15 U.S.C. \& 77aaa (1958). For vigorous criticism of the Commission's Report on indenture trustees, see McCollom, The Securities and Exchange Commission and Corporate Trustees, 36 CoLuMr. L. REv. 1197 (1936); Wham, Trustees Under Indentures, 23 A.B.A.J. 179 (1937). For more favorable comment, see Posner, The Trustee and the Trust Indenture: $A$ Further Study, 46 Y YLE L.J. 737 (1937); Comment, Protection for Debenture Holders, 46 YALE L.J. 97 (1936). 
tion, if they acquire conflicts of interest not compatible with their fiduciary obligations. ${ }^{108}$ The objective of this legislation is to transform the trustee from the passive position which he customarily assumed prior to the adoption of the Act to that of an active trustee with affirmative fiduciary obligations to the holders of the indenture securities. ${ }^{109}$

Recommendations were also made for the reform of protective committees. ${ }^{110}$ Strangely enough, however, nothing tangible came of these proposals inasmuch as the Lea Bill, ${ }^{111}$ following hearings, ${ }^{112}$ expired in the House Committee on Interstate and Foreign Commerce.

Although it was the purpose of Chapter $\mathrm{X}$ to give reorganization procedures a good scrubbing, the experiment so far has not been overly successful. Corporate debtors increasingly find it possible to avoid the pervasive regulation of Chapter $\mathrm{X}$ by the use of the arrangement procedure prescribed in Chapter XI of the Bankruptcy Act. Chapter XI was enacted at the time of the passage of Chapter X, presumably for the purpose of providing a more simplified procedure for adjusting unsecured creditors' claims against small distressed companies. ${ }^{113}$ Whereas Chapter X, as developed by the Protective Committee proposals, surrounds the reorganization process with an elaborate system of safeguards for the protection of creditors, Chapter XI permits the perpetuation of the old reorganization system, with statutory sanction. In effect, the arrangement procedure provided in Chapter XI is merely an adaptation of the informal composition process, previously authorized by section 12 and 74 of the Bankruptcy Act, with its accent on the spirit of "friendly compromise." Nevertheless, Chapter XI eliminated two of the fatal defects of the informal, extra-judicial procedures to be found in such compositions: the threat of involuntary bankruptcy and the absence of power to compel recalcitrant creditors to accept an arrangement which would postpone liquidation for the purpose of allowing the business to continue in the hopes of riding out the financial storm. ${ }^{114}$ Chapter XI was the product of a successful campaign

108. Section 310 (b), 53 Stat. 1158 (1939), 15 U.S.C. $\$ 77 \mathrm{jjj}$ (b) (1958). Exculpatory clauses seeking to immunize the trustee from the normal obligations of a fiduciary are prohibited. Minimum standards are now prescribed for indentures as a condition to qualification: under the Act. Section 315, 53 Stat. 1171 (1939), 15 U.S.C. § 77ooo (1958).

109. For the background and an analysis of the Barkley Bill see Banks, Indenture Sectrities and the Barkley Bill, 48 YALE L.J. 533 (1939). On the Trust Indenture Act, see 2 Loss, Securities Regulation 720-53 (1961).

110. SEC REPORT, pt. VIII at 308-36.

111. H.R. 6968, 75th Cong., 1st Sess. (1937). For a critique of the Lea Bill see the articles cited in note 79 supra.

112. Hearings on H.R. 6968 Before the House Committee on Interstate and Foreign Commerce, 75th Cong., 1st Sess. (1937).

113. See Douglas, Democracy and Finance 174 (Allen ed. 1940); Rostow \& Cutler, Competing Systems of Corporate Reorganization: Chapters $X$ and $X I$ of the Bankruptcy Act, 48 YaLE L.J. 1334, 1337 (1939).

114. Rostow \& Cutler, supra note 113, at 1337. Under Chapter XI, however, only the rights of the unsecured creditor may be adjusted and this must be accomplished without tampering with the status of any other class of securityholders. 
waged by the National Association of Credit Men and the National Bankruptcy Conference, the latter being comprised of a self-appointed group of bankruptcy lawyers and other persons who are in the inner circle of the bankruptcy establishment. These groups were interested in establishing a speedy, economical and informal judicial machinery for dealing with insolvent debts, with none of the nonsense surrounding Chapter $X$. They were also interested in preserving the lucrative stakes in various facets of bankruptcy practice. ${ }^{115}$

Chapter XI is the antithesis of Chapter X. The absence of safeguards comparable to those found in Chapter X was described by Mr. Justice Stone in $S E C$ v. United States Realty \& Improvement Co. in this way:

Every phase of the procedure bearing on the administration of the estate and the development of the arrangement is under the control of the debtor. The process of formulating an arrangement and the solicitation of consent of creditors, sacrifices to speed and economy every safeguard, in the interest of thoroughness and disinterestedness, provided in Chapter X. The debtor is generally permitted to stay in possession and operate the business under the supervision of the Court, section 342 , and a trustee is provided for only in the case where a trustee in bankruptcy has previously been appointed and is in possession, or if "necessary" a receiver may be appointed. Section 332. The debtor proposes the arrangement, sections $306(1), 323,357$, and the only opportunity afforded the creditors in respect to the proposed plan is to accept or reject it as submitted by the debtor. Acceptances may be solicited either before or after filing the petition and always before approval of the plan by the Court, section 336(4). Section 361 authorizes confirmation of an arrangement when accepted by all the creditors affected by it, "if the court is satisfied that the arrangement and the acceptance are in good faith," and section 362 permits confirmation if only a majority of the creditors affected accept. ${ }^{110}$

Added to this is the absence of provision for investigations of the debtor's affairs by an independent trustee of the court. Furthermore, creditors' committees are permitted but there is no control over their selection and conduct such as that found in Chapter X. ${ }^{117}$ The arrangement may be formulated by the debtor and the leading creditors and approval at a meeting of creditors may be mere ceremony. The Court, in passing on the arrangement, lacks the independent advice of a trustee or the SEC as required in Chapter $\mathrm{X}$ and generally its approval becomes perfunctory in the face of the fact that a majority of creditors have already approved the plan.

The threat to Chapter X stemming from the existence of these two systems of reorganization was pointed out in the classic article by Rostow and Cutler in the pages of this Journal, shortly after the enactment of the legislation. ${ }^{118}$ Over the years, Chapter $\mathrm{X}$ has more and more faded into the background as bankruptcy lawyers have learned how to stage a Chapter XI proceeding so

115. Ibid. See SEC v. United States Realty \& Improvement Co, 310 U.S. 434, 450 n.8 (1940).

116. 310 U.S. 434, 450-51 (1940). Cf. Rostow \& Cutler, supra note 113, at 1344.

117. Sections 334, 338, 52 Stat. 908 (1938), as amended, 11 U.S.C. $\$ \$ 734,738$ (1958).

118. Rostow \& Cutler, supra note 113. 
as to keep it out of Chapter X. In General Stores Corp. v. Shlensky ${ }^{119} \mathrm{Mr}$. Justice Douglas, as a member of the Supreme Court, attempted to delineate the respective jurisdiction of Chapter $\mathrm{X}$ and Chapter XI. Further consideration of this problem will therefore be postponed until that case is considered. ${ }^{120}$

\section{B. Stock Exchange Reform}

From the moment he became SEC Commissioner in January, 1936, Douglas began to concentrate upon the operation of the securities markets and particularly the New York Stock Exchange. While continuing to direct the Protective Committee Study, he also became the Commissioner responsible for the important Division of Trading and Exchanges, the unit that monitors the stock exchanges. ${ }^{121}$

The Securities Exchange Act of $1934{ }^{122}$ had given the Commission vast powers over the exchanges. Thus, if the public interest and the protection of investors demanded, it could investigate stock exchange practices and make, impose and enforce trading rules. ${ }^{123}$ Section 11 gave the power to regulate or prevent floor trading by members for their own or for discretionary accounts. Specialists and odd-lot dealers were also subject to regulation. In addition, Congress had directed the Commission to study the feasibility and advisability of the complete segregation of the functions of dealer and broker and report to it the results of its study and recommendations.

The New York Stock Exchange traditionally had opposed any change in the existing system, which permitted one person to combine these functions, thus enabling him to act as an agent and fiduciary for others without foregoing the right to trade for his own account. The system inevitably created a conflict of interest between the broker-dealer and his customer, when both dealt in the same stock. It also gave material advantages to the floor member as compared to public customers, by virtue of his presence on the floor and the lower trading costs arising from exchange membership. ${ }^{124}$

Despite the broad powers conferred by the 1934 Act, the Commission had backed away from adopting trading rules, except those forbidding pools and market manipulation. During the Chairmanship of Joseph P. Kennedy, however, it had prodded the New York Stock Exchange and other exchanges to adopt the so-called Kennedy trading rules. ${ }^{125}$ These rules, among other things,

119. 350 U.S. 462 (1956).

120. See notes 223-25 infra and accompanying text.

121. Rodell, supra note 71 , at $116-20$.

122. 48 Stat. 881 (1934), 15 U.S.C. $\$ \$ 78 \mathrm{a}-78$ jj (1958).

123. Securities Exchange Act of 1934, §§ 11, 19, 48 Stat. 891, 898 (1934), 15 U.S.C. $\S \S 78 \mathrm{k}, 78 \mathrm{~s}(1958)$.

124. See SEC, Report on the Feasibility and Advisability of the Complete Segregation of the Functions of Dealer and Broker 14-21 (1936); Douglas, Democracy and Finance 96 (Allen ed. 1940).

125. After a comprehensive survey of the activities of specialists, floor traders, and odd-lot dealers on the New York Stock Exchange and other exchanges, the Commission formulated "suggested" rules for the regulation of trading. These rules were sent to the 
sought to make it difficult to sell short on a falling market by forbidding short sales below the last reported sale. The specialist system, whereby a floor member who is registered as a specialist in one or more stocks is allowed to act as broker for the account of other members and their customers, as well as deal in such stock or stocks for his own account, was continued; however, a specialist combining the two functions could trade for his own account only where reasonably necessary in order to permit him "to maintain a fair and orderly market." The interpretation of these rules frequently entailed the application of subjective standards, and the exchanges had shown little inclination to use disciplinary measures against members caught breaking the rules. This attitude in part stemmed from the fact that infractions of the rules were regarded as a purely private affair of no concern to the public. Moreover, the governing board of the New York Stock Exchange was dominated by the specialist and floor-trader groups, whereas commission brokers who deal directly with the public had little effective representation. ${ }^{120}$

With matters in this posture, the Commission, in June, 1936, sent its report on the feasibility and advisability of segregating the functions of dealer and broker to Congress. ${ }^{127}$ Although the report was "preliminary in character" it did look eventually toward a "functional segregation of all members on the floor of the exchange with the exception of the specialist in the stocks in which he specializes." 128 This requirement would prevent floor traders from acting as brokers; and floor brokers and commission brokers could not, while on the floor of the exchange, initiate orders for their own account or for the account of their firms. Other proposals were made for control of floor trading, for restrictions on the activities of specialists, and for trading by members in stocks off the floor of the exchange. ${ }^{129}$

Whether or not triggered by the segregation study, shortly after the publication of this report Mr. Charles R. Gay, President of the New York Stock Exchange, spoke out in favor of continuing to allow stock market speculation by professional traders as indispensable to the maintenance of market liquidity.

exchanges with the Commission's request that they be adopted. Most exchanges adopted the rules as recommended or with modifications. 1 SEC ANN. REP. 13-14 (1935). The rules may be found in $i d$. at $40-44$.

126. In a report to Congress in January, 1935, the Commission had made a number of recommendations for changing the rules of the exchanges in order to give a better balance in exchange government to commission firms, thus insuring fairer representation of the membership and better enforcement of disciplinary rules. H.R. Doc. No. 85, 74th Cong., 1st Sess. 17 (1935). The proposal was directed primarily at the New York Stock Exchange; it contemplated "voluntary" action by the exchanges rather than direct legislation. See SEC Report, Spectal Study of Securities Markets of the Securities and Exchange Connartssion, pt. 4 at 506 (1963). [Hereinafter cited as SEC Specral. STUDY.]

127. SEC, Report on the Feastbility and Advisability of the Complete Segregation of the Functions of Dealer and Broker (1936).

128. Id. at iii. See Douglas, Democracy and Finance $96-97$ (Allen ed. 1940).

129. See note 127 supra. 
It was his opinion that the margin restrictions imposed by the Federal Reserve Board (which were then set at forty-five per cent of current value as compared with the current seventy per cent limitation) together wih SEC regulation had contributed to make the markets so thin that relatively small increases in the volume of transactions tended to cause undue fluctuations in prices. The market break of 1936 was thought to illustrate the point. ${ }^{130}$

Commissioner Douglas immediately challenged this view..$^{131}$ If the rules and regulations under the 1934 Act had contributed to market "thinness," they were the same rules which had been devised to prevent manipulation and controlled prices, to prevent the excessive use of credit in stock market speculation, to remove the advantages accruing to insiders, and to regulate trading by professionals. Furthermore, "liquidity" based upon short-term trading by professionals or excessive speculation by the public brings about an "artificial instability" which is a "fertile ground for abuse and actual fraud, for distorting the real prices, by divorcing them, through an intervening speculative enthusiasm or despondency, from their economic background."132 His objective was neither to create "thin" markets nor "thick" markets, but to protect investors by curbing speculative excesses (which itself was damaging to the economy) and by the imposition of higher fiduciary standards for stock market professionals. ${ }^{133}$

Invited to speak to the students at the New York Stock Exchange Institute, a training school for employees of member firms, Commissioner Douglas used the occasion to discuss the ethics of the brokerage profession and their impact upon young people entering the profession. ${ }^{134}$ He referred "to the practice of gentlemen teaching youth gentlemanly ways of redistributing the wealth of their clients so that they may get an inordinate share of it in extravagant ways," and then added:

Our educational system has been too virile in production of men immunized from a sense of feeling of social responsibility, trained in the art of plunder in gentlemanly ways, imbued with the false ideal that the American way means exploitation. There has been too little emphasis on the principle that the basic essential of an education is the ability to think - to think in terms of human values, to think in terms of social responsibility, to think in terms of what the cumulative effect of your daily activities is in terms of your clients' welfare and of your character. ${ }^{135}$

130. 145 Commercial and Financlat. Chronicle 1185 (1937) (Mr. Gay's annual report to the N.Y.S.E.) ; N.Y. Times, July 8, 1936, p. 27 , col. 1; id. July 12, 1936, § 3, p. 1 , col. 8 ; $i d$. Nov. 30, 1937, p. 12, col. 2; Douglas, Denocracy and Finance 92 (Allen ed. 1940).

131. His speech on "Margins and Markets" is reprinted in Douglas, DeMocracy and Finance 91-106 (Allen ed. 1940).

132. Id. at 103.

133. Id. at 106.

134. This speech on "Customers' Men" aroused a tempest in the financial community. It appears in DougLas, op cit. supra note 130, at 107-19.

135. Id. at $108-09$. 
The need to think in these terms is especially imperative in those professions affected with a public interest such as the brokerage profession, which holds itself out as rendering independent investment advice.

The investment banking community came in for biting criticism in the famous "Bond Club Speech," made to the Bond Club of New York. ${ }^{136}$ They were told that in large segments of their business a noncompetitive condition prevailed; that investment bankers had in effect usurped the rights of the great body of investors and that the condition could only be described as financial royalism. As a means of breaking the monopoly of finance and eliminating conflicts of interest he proposed that: (1) bankers be removed from the directorates of industrial companies; (2) underwriting be divorced from security selling; (3) voting trusts and nonvoting stock - devices by which the dominant groups engaged in "corporate kidnaping" — should be banned; and (4) bona fide competitive bidding should be required in the sale of all corporate issues. ${ }^{137}$

Since Commissioner Douglas was regarded as a likely candidate to succeed Chairman Landis, who was about to retire, his aggressiveness and passion for reform, as manifested particularly in these talks, shocked the financial community and generated considerable hostility to his elevation to the chairmanship. ${ }^{138}$ Although the Chairman was elected by the Commission itself, it was generally understood that the Commission would not appoint anyone opposed by President Roosevelt. ${ }^{139}$ Any hopes that the young Commissioner might be bypassed as "a gracious gesture to the financial community" were dashed however in September, 1937, when he was elected Chairman of the Commission. ${ }^{140}$

The new Chairman immediately opened negotiations with the New York Stock Exchange for the reform and reorganization of the Exchange government. But the talks had hardly begun when the stock market suddenly collapsed in October, 1937. The break, one of the sharpest in market history, touched off attacks from the financial community attributing the market plunge in part to overregulation by the government. ${ }^{141}$ After a series of conferences in

136. Id. at $32-45$.

137. The speech signaled the later adoption of the SEC competitive bidding rule covering debt securities marketed by public utility holding companies and their subsidiaries. SEC Holding Co. Act Release No. 2676, April 8, 1941; 17 C.F.R. $\$ 250.50$ (1949).

138. For magazine comment, see Business Week, April 3, 1937, p. 34; Time, April 5, 1937, p. 71.

139. N.Y. Times, Aug. 10, 1937, p. 25, col. 6.

140. Business Week observed that the Bond Club Speech "lifted Douglas from the crowd. It ired Wall Street, but it undoubtedly impressed President Roosevelt, who has never lost any love on the 'money changers,' and it unquestionably influenced the selection of Douglas as successor to James M. Landis. Douglas had become a 'spokesman' for the SEC." Business Week, Sept. 25, 1937, p. 60.

141. For one "inside story" of the behind-the-scenes battle between the Old Guard of the New York Stock Exchange and Chairman Douglas as spokesman of the SEC, see Rodell, Donglas Over the Stock Exchange, Fortune, Feb. 1938, p. 64. 
which Exchange representatives submitted their plan for reorganization of the Exchange, negotiations suddenly broke off in November, 1937, when the Commission made it clear that the proposed reforms were unsatisfactory.

The impasse came to light when Chairman Douglas issued a public statement warning the Exchange to put its house in order by means of self-regulation or face more pervasive direct regulation by the Commission under the powers granted in the 1934 Act. ${ }^{142}$ To him the time had come for the Exchange to stop administering its affairs as if it were a private club. For a business so affected with the public interest, this traditional method of operaton had become archaic. The basic problem centered upon the permissible field of operation of the floor trader, the specialist and the odd-lot dealers. With statistics to support him. Douglas contended that there was a strong tendency for the floor professionals to accentuate market swings by selling short for speculative profit at a time when the market was declining and buying heavily on margin in an upward swing, thus contributing to the severity of price fluctuations. These professional traders were the same group that dominated the Exchange government and blocked any reform that might limit their profit opportunities. ${ }^{143}$ Furthermore, the private club atmosphere was not conducive to internal policing of these professionals for infractions of the Exchange trading rules.

Replying to the threat to reorganize or face further Federal regulation, President Gay of the New York Stock Exchange defended the existing system as best serving the public interest. ${ }^{144}$ Nevertheless, in December, 1937 he announced the appointment of the Conway Committee to study the organization and administration of the Exchange and make recommendations. ${ }^{145}$ In January, 1938, the Conway Committee made its report, recommending sweeping changes as to the Exchange's method of operation. It was proposed that the board of governors include office partners of member firms, both those based in New York City and out-of-town, and that three new members of the board be appointed to represent the public. A new office of chairman of the board was to be created. A nonmember full-time paid president was to be elected with authority to appoint all officers except the chairman and vice chairman. A permanent executive staff was to be developed under the direct supervision of the President to administer Exchange affairs on a business-like basis, thus relieving committee members of administrative details and enabling them to concentrate on policy. By May, 1938, these recommendations had been approved by the membership and the new rules had become effective. ${ }^{146}$ The reorganization met the approval of the Commission and Chairman Douglas was invited to be the speaker at a dinner given by the Association of Stock

142. N.Y. Times, Nov. 24, 1937, p. 1, col. 5, p. 31, col. 2. Douglas, Democracy and Finance 63-73 (Allen ed. 1940).

143. Id. at $67-70$.

144. N.Y. Times, Nov. 30, 1937, p. 1, col. 7, p. 12, col. 2.

145. The official version of the controversy may be found in 4 SEC ANN. REP. 20-22 (1938).

146. SEC Special Study pt. 4, at 506-09. 
Exchange Firms to honor the Conway Committee. In a gracious speech, he hailed the reorganization as a joint achievement exemplifying the self-regulation principle at its best and called for a joint program to be worked out at the conference table for increasing the effectiveness of the Exchange as a vital $\operatorname{cog}$ in the financial machinery of the nation. ${ }^{147}$

Largely as a result of the 1938 Exchange reform program, the New York Stock Exchange now occupies a position of first rank among self-regulatory institutions. This is not to suggest that all or even most of the problems which confront the SEC and the Exchange have been solved. Indeed, the recent SEC Special Study Report disclosed that although the performance of the Exchange as a self-regulatory agency is quite high there is still an unsatisfactory discharge of function in some areas. In assessing the reasons for failure of the system in certain respects the Special Study cites the disproportionate number of floor professionals in the government of the Exchange, stemming ultimately from the allocation of voting power under the Exchange constitution. Other cardinal problems revolve around regulation of floor traders, specialists and odd-lot dealers, for the basic problem of whether there should be further segregation of the function of dealer and broker has never been resolved. The Special Study found that the surveillance program applicable to floor traders and specialists has been inadequate in total effect.148 Furthermore the Commission is still seeking to devise some way of curbing the "Customer's" man from using high pressure methods in dealing with the public and to force brokers to engage in better branch office supervision. ${ }^{148}$ Finally, in the disciplinary area, the Special Study found that the Exchange still leans toward tenderness rather than severity in meting out punishment; and that the Exchange still follows the policy of not publicizing the names of or the penalties imposed upon member firms or persons for infractions of its rules. ${ }^{150}$ Even so, the 1938 reforms established a pattern of self-regulation that makes the Exchange the exemplar of this method of securities control. For as Chairman Douglas told a congressional committee at the height of his confrontation with the Exchange, the key to this form of regulation was to be found in ". . . letting the exchanges take the leadership with Government playing a residual role. Government would keep the shotgun, so to speak, behind the door, loaded, well oiled, cleaned, ready for use but with the hope it would never have to be used."151 The lesson of the 1938 reform both for the Exchange

147. Douglas, Democracy and Finance 79-91 (Allen ed. 1940).

148. SEC Special Study pt. 4, at 550-57, 573-74.

149. Id. pt. 1, at 242-330, 542-44.

150. The present controversy over the role of the specialist, elimination of the floor trader and the problem of odd-lot trading is merely a continuation of a conflict between the Commission and the stock exchanges that has still to be resolved. The arguments for and against the SEC proposals show no perceptible change over the years. See SEC Spectal Study pt. 4, at 504-84.

151. Dougras, Democracy and Finance 82 (Allen ed. 1940). 
and the Commission is that there is more to be gained by joint cooperation than by open conflict, so long as the shotgun remains handy.

With stock exchange reform under way, Chairman Douglas pressed for a similar program of self-regulation among brokers and dealers engaged in the over-the-counter markets.

\section{The NASD - A Venture in Cooperative Regulation of the Over-the-Counter Markets}

The over-the-counter markets pose a baffling problem in securities regulation. At the time of the enactment of the Exchange Act these markets were somewhat of a mystery. A stock exchange is an organized institution with a limited and preselected membership. Trading is confined to a choice group of securities that have met fairly rigorous listing requirements. All transactions are conducted at a central place, the floor of the exchange; there securities are bought and sold at public auction at prices that are flashed to brokers' board rooms throughout the nation by electronic means.

In the over-the-counter markets different conditions prevail. The size of the market, in terms of the number of issues traded, knows no limits. In 1938, when the Commission was taking a fresh look at the problem, about 6,000 separate issues of stocks and bonds were being traded on all of the stock exchanges; however, over-the-counter quotations for at least 60,000 different issues of securities were being published in the various services to which brokers and dealers subscribe. Furthermore, of the 6,766 firms of brokers and dealers registered with the Commission as conducting an over-the-counter business, only 1,371 were members of an organized exchange. ${ }^{152}$

Brokers and dealers transact business in the over-the-counter market as market makers in particular stocks or simply act as brokers or dealers. ${ }^{163}$ The market actually consists of nothing more than a network of telephone lines or other forms of communication connecting these firms throughout the country; trading goes on back and forth frequently at long distances and always in privacy. Although there are printed lists of bid and asked prices for the private use of these firms or for newspaper publication, these quotations do not reflect the actual prices at which a security is being traded and that information is nowhere accessible. ${ }^{154}$ This lack of information heightens the regulatory problem. ${ }^{155}$ It is not surprising, therefore, that in 1934 when the Exchange Act was adopted, although the necessity of regulating the over-thecounter market so as not "to destroy the effects of regulating the organized

152. S. REP. No. 1455, 75th Cong., 3d Sess. 2 (1938).

153. The diversity, nature and organization of the wholesale and retail markets are described in SEC SPECIAI STUdy pt. 2, at 554-658.

154. For a description of the wholesale and retail quotation systems, see SEC Special Study pt. 2, at 595-609, 630-43.

155. SEC SPECIAL STUDY pt. 2, ch. VII contains a thoroughgoing study of the overthe-counter markets and goes far to dispel this lack of knowledge. 
exchanges"156 was generally recognized, the policing problem as such seemed overwhelming.

The Exchange Act defines the over-the-counter market to include all transactions in securities which take place otherwise than on a national securities exchange. ${ }^{\mathbf{1 5}}$ Rather than any specific form of regulation, Congress gave the Commission a broad grant of power to make such rules in the public interest as were necessary or appropriate "to insure to investors protection comparable" to that provided in the Exchange Act for securities traded on one of the stock exchanges. ${ }^{158}$ Enforcement was to be effected through regulating brokers and dealers by prohibiting them from using the mails or interstate facilities to effect transactions in securities outside of the organized exchanges in contravention of the Commission's rules. But the proxy regulation, insider trading and reporting provisions of the Exchange Act operated directly upon listed companies; and it was not thought feasible to make "comparable" regulations applicable to over-the-counter companies which could be reached, if at all, only indirectly by applying sanctions against dealers trading in their securities. In 1936 the Exchange Act was amended to withdraw this broad delegation. In its place section 15 was amended to establish a system of registration for brokers and dealers (other than those whose business was exclusively intrastate) who use the mails or interstate facilities "to effect any transaction in, or to induce the purchase or sale of, any security," other than certain exempt securities. ${ }^{159}$

We have already noted that this brought almost seven thousand different firms under the registration provisions, but this was only a beginning to the solution of the problem. In 1937 the Commission ran an investigation limited to three areas outside the largest financial centers - Cleveland, Detroit and the Pacific Northwest. In the space of a few months a team of lawyers and accountants uncovered violations which led to the conviction of thirteen individuals, the indictment of 16 others, injunctions against 17 corporations and 41 individuals and the expulsion or withdrawal of two firms from the securities business, all for elementary violations of the securities laws. ${ }^{160}$ It was obvious that direct regulation of such numbers of persons in widely scattered areas would call for an enormous increase of Commission manpower. At the same time, however, industry self-regulation was impossible under the unorganized conditions which existed. As Commissioner Matthews described the problem :

[It] is a little like trying to build a structure out of dry sand. There is no cohesive force to hold it together, no organization with which we can build .... ${ }^{161}$

156. Twentieth Century Fund, The Security Markets 668 (1934).

157. 52 Stat. 1075 (1938), 15 U.S.C. \& 780 (a) (1958).

158. Securities Exchange Act of 1934, \& 15, 48 Stat. 895 (1934).

159. 49 Stat. 1377 (1938), 15 U.S.C. \& 780 (1958).

160. S. ReP. No. 1455, supra note 152 , at 3.

161. SEC Spectal Study pt. 4, at 604 . 
It will be recalled that, even before he came to the Commission, Douglas had advocated a form of securities control "which would combine regulation by industry with supervision by government."162 Although to the stock exchanges, at least prior to the 1938 reform program, self-regulation meant little or no governmental oversight, responsible representatives of the overthe-counter business themselves sought some form of self-regulation with supervision by the Commission. Senator Maloney of Connecticut, who sponsored the necessary legislation in the Congress, described this joint effort as "a system for cooperative regulation of the over-the-counter markets." 183

Such an undertaking required some form of institutional organization. The nucleus for such an organization was provided by the Investment Bankers Code Committee, which under the National Recovery Administration (NRA) had prepared and enforced an industry-wide code of fair competition. ${ }^{164}$ After the death of the Blue Eagle, the code committee was kept in existence through the encouragement of the Kennedy and Landis Commissions. ${ }^{165}$ In 1935 it was supplanted by the Investment Bankers Conference Committee, whose function was to establish a voluntary form of industry self-regulation under SEC auspices and supervision. The conclusion was soon reached, however, that the objectives of the organization could not be attained without implementing legislation, particularly legislation providing an exemption from the antitrust laws. ${ }^{106}$ In October, 1936, a new group emerged, the Investment Bankers Conference (IBC). In a series of roundtable discussions between the Douglas Commission and that body, agreement was reached on a joint legislative program which culminated in 1938 in the passage of the Maloney Act, adding section $15 \mathrm{~A}$ to the Securities Exchange Act of $1934 .{ }^{167}$ Chairman Douglas appraised the alternative approaches to regulation of the over-the-counter markets and the philosophy underlying the Maloney Act in terms of an articulate preference for self-regulation under federal supervision. ${ }^{168}$

In a nutshell, section $15 \mathrm{~A}$ authorizes the registration of any association of brokers and dealers as a national securities association if the Commission finds certain statutory conditions have been met. These conditions seek to assure that the composition and internal government of the association will further the purposes of cooperative regulation. The National Association of

162. Douglas, Protecting the Investor, 23 YaLE REv. (n.s.) 521, 532 (1934).

163. S. Rep. No. 1455 , supra note 152 , at 1 ; see address of Senator Francis T. Maloney to California Security Dealers Association, Investment Bankers Association, and NASD, San Francisco, Aug. 22, 1939, p. 3.

164. For the historical background on the NASD, see SEC SPEciar Study pt. 4, at 604-07.

165. Ibid.

166. Ibid.

167. For the legislative history of the Maloney Act, see S. REP. No. 1455 and H.R. REP. No. 2307, 75th Cong., 3d Sess. (1938).

168. Address before the Bond Club of Hartford, Connecticut, Jan. 7, 1938, printed in the Conference News, published by the Investment Bankers Conference, Inc., vol. 1, No. 11A, Jan. 8, 1938. 
Securities Dealers is the only association thus far registered with the Commission under this section of the Exchange Act. The NASD is a nonprofit corporation with the clearly stated objective of raising the professional standards of securities firms engaged in an over-the-counter business. ${ }^{109}$

The most complete and recent analysis of the NASD as a self-regulatory institution is that contained in the SEC Special Study. ${ }^{170}$ Over the years the association has grown so that by December 31, 1962 its membership had reached 4,771, or 83 per cent of the 5,724 firms registered as broker-dealers under the Exchange Act. Its registered representative program covered 94,444 individuals, comprising the vast majority of the securities salesmen of the country. 171

Under its objectives to promote "high standards of commercial honor" and "just and equitable principles of trade for the protection of investors" the association has adopted a number of policies "lying beyond the periphery of the law in the realm of ethics and morality." Among the most noteworthy are the " 5 per cent mark-up philosophy",; $;$ the rule of "suitability" of investments for each customer based upon his financial holdings and investment needs; ${ }^{173}$ the rules against churning and excessive activity ${ }^{\mathbf{1 7 4}}$ the interpretation of the rules of fair practice to prohibit "free-riding and withholding" by participants in underwritings; $;{ }^{175}$ and the recent practice of reviewing members' offerings of unseasoned companies to determine whether the underwriting arrangements are fair and reasonable, under all of the circumstances of the offering. ${ }^{176}$ These innovations support the view of the Special

169. The Certificate of Incorporation states the following objects of the association:

(1) To promote through cooperative effort the investment banking and securities business, to standardize its principles and practices, to promote therein high standards of commercial honor, and to encourage and promote among members observance of Federal and State securities laws;

(2) To provide a medium through which its membership may be enabled to confer, consult, and cooperate with governmental and other agencies in: the solution of problems affecting investors, the public, and the investment banking and securities business;

(3) To adopt, administer, and enforce rules of fair practice and rules to prevent fraudulent and manipulative acts and practices, and in general to promote just and equitable principles of trade for the protection of investors;

(4) To promote self-discipline among members, and to investigate and adjust grievances between the public and members and between members. . .

170. SEC Spectal Study pt. 4, at 602-82.

171. Id. at 603 .

172. The policy is stated in NASD Manual, p. G-1. And see Jennings \& MarsH, Securities Regulation-Cases 719-21. The genesis, scope and effectiveness of the policy are described in SEC SpEciar Study pt. 2, at 645-53.

173. SEC Special Study pt. 1, at 308-14. For an application of the rule, see Boren \& Co., SEC Securities Exchange Act Release No. 6367, Sept. 19, 1960.

174. SEC Spectal Study pt. 4, at 658.

175. Id. at 660-61.

176. See Current Problems of Securities Underwriters and Dealers, $A$ Symposium of the ABA Section of Corporation, Banking \& Business Law, San Francisco, Ang. 6, 1962, 18 Bus. Law. 27, 44-48 (1962); SEC Special Study pt. 4, at 661. 
Study that "the NASD has many important accomplishments to its credit, and its history evidences a clear desire to expand the role of self-regulation in the total regulatory scheme and to make self-regulation work."177 Nevertheless, the Special Study concludes that the NASD has fallen short of its potential as a self-regulatory institution, primarily because it has consciously chosen to administer its affairs and enforce its disciplinary rules largely through its own nonpaid membership rather than through the development of a professional staff adequate to discharge its regulatory responsibilities. In other words, the NASD finds itself substantially in the same administrative impasse that the Conway committee found the New York Stock Exchange in 1937. ${ }^{178}$ Although the building of an enlarged staff will mean additional expense for the membership, the relatively brief history of the association indicates that the membership is prepared to finance the costs entailed in modifying and strengthening its organizational structure. In any event, however, the association's record of accomplishment has fulfilled the expectations which Chairman Douglas held out for it in 1938.

In April, 1939 Douglas departed from the Chairman's office of the SEC for the Supreme Court of the United States. In the words of Mr. Arthur Krock: ". . . having been so suddenly lifted from the bullring to the stratosphere of public service the smell of blood and sand ... [was] still strong in his nostrils. ... [H] discussed the commission and its problems as though they were to remain as much a part of his life as they were a couple of weeks ago."179 To him the activities of the commission had reached their practical peak. The task of the future, as he saw it, was "to tighten and lubricate the machine, smooth and perfect its action and somewhat readjust its governor." $180 \mathrm{He}$ warned against an increase in the size or functions of the agency: "Men soon reach the limit of our resources and capabilities. The wise thing to do is to recognize that limit and not attempt to stretch it."181 On the legislative side, he proposed that at some future time an eminent drafting committee, representing all legitimate interests, should undertake to consolidate and perfect the Securities Act and the Exchange Act, to eliminate duplications, ambiguities and what are probably some unintended exactions on honest business. With his departure the Douglas era in the Commission's history ended, but his philosophy is still a pervading force in policy making by that body.

\section{Mr. Justice Douglas on Corporate and Securities Regulation}

Considering the whole range of cases relating to economic law, those involving questions of corporate reorganizations and of corporate and securities regulation do not bulk large in the work of the Supreme Court. Over the

177. SEC Spectal Study pt. 4, at 673.

178. See note 145 stipra.

179. N.Y. Times, March 29, 1939, p. 22, col. 5.

180. Ibid.

181. Ibid. 
last quarter century, however, Mr. Justice Douglas has continued to exert a powerful influence on the path of the law in these fields through a number of landmark opinions. ${ }^{182}$

\section{A. Corporate Reorganizations}

1. The rule of "absolute priority." Some of the Justice's most controversial opinions in corporate reorganizations have dealt with two rival theories concerning the priorities to be accorded various classes of security holders. Competing for supremacy were the theories of "absolute priority" and of "relative priority." The objective in reorganizations is to continue the business, rather than liquidate and pay off the security holders in cash. "Fairness" requires that the new securities be distributed among the various classes of security holders, according to their priorities. The theory of "absolute priority," as commonly understood, would require that, in the hierarchy of claims, senior securities should always receive securities having a "value" equal to principal plus unpaid interest (or liquidation value plus accrued dividends in the case of stock) before anything could be given to the next class of securities. By one of those odd coincidences that enliven history, the rival "relative priority" theory was that advocated by Robert T. Swaine, Justice Douglas' old mentor. In 1927 in a lecture before the Bar Association of the City of New York, Swaine traced the judicial treatment of the Boyd case ${ }^{183}$ in subsequent decisions and concluded :

The rule as I see it, and as I believe it will ultimately be developed by the courts, is that the relative priorities of the old securities, senior to the most junior securities which continue to have any interest in the property, must not be inequitably disturbed. ${ }^{184}$

In general, the "absolute priority" theory tended to respect the contractual rights of the various parties and to favor the senior security holders over the junior claims and equity interests. The "relative priority" theory, on the other hand, left a greater opportunity for negotiation as between the senior and junior securities, so long as their relative rights were not "inequitably disturbed." Thus, it came to be known as the "composition theory."185 Since the junior securities were more likely to be identified with management of the debtor, corporate reorganizers allied with the debtor's management or its bankers were inclined to advocate the theory of "relative priority." The controversy was ventilated in the now classic article by Bonbright and Ber-

182. Countryman, Douglas of the Suprene Court (1959) contains a biographical sketch of the Justice and a representative selection of his opinions.

183. Northern Pac. Ry. v. Boyd, supra note 56.

184. Swaine, Reorganization of Corporations: Certain Developments of the Last Decade, 27 Colum. L. Rev. 901, 907 (1927) (emphasis supplied); 8 Lectures on LEGal Topics 133, 142 (1931).

185. Rostow \& Cutler, supra note 113, at 1355; SEC REPORT pt. VIII, at 145 (1940); Marine Harbor Properties, Inc. v. Manufacturers Trust Co., 317 U.S. 78, 86 (1942) (Douglas, J.). 
german in which they weighed the merits of the two rival theories. ${ }^{186}$ They noted that the issue had been sharply drawn in the famous St. Paul reorganization, ${ }^{187}$ where the Committce representing the dissenting bondholders contended, among other things, that the plan of reorganization (defended by Mr. Swaine) was unduly favorable to the stockholders. The failure of these objections to persuade the courts led these writers to speculate whether there had not been a judicial rejection of the absolute priority doctrine. ${ }^{188}$

After a decade of controversy over these rival theories, the problem reached the Supreme Court in the famous Los Angeles Lumber. case, ${ }^{189}$ decided in 1939 and the Consolidated Rock Products case ${ }^{190}$ decided in 1941. Mr. Justice Douglas spoke for an unanimous Court in each case.

The Los Angeles Lumber case involved a section 77B reorganization of a company having an outstanding bond issue representing a liability of principal and interest of some $\$ 3,800,000$. The district court found that the debtor's total assets did not exceed $\$ 900,000$ and that it was insolvent both in the equity and bankruptcy sense. The plan of reorganization, prepared by management, called for the transfer of the assets to a new company having a capital structure of $1,000,000$ shares of $\$ 1$ voting stock, divided into 811,375 shares of preferred and 188,625 shares of common. After the reservation of 170,000 shares of preferred for sale to raise money to rehabilitate the plant, 641,375 shares were to be issued to the bondholders, 250 shares in exchange for each $\$ 1,000$ bond. The old Class $A$ shareholders were to receive the entire 188,625 shares of common without the payment of any fresh money. The plan had received the assent of more than ninety per cent of the face amount of the bonds, the Class A stock, and the Class B stock.

The plan was attacked by plaintiff-bondholders on the ground that it was not "fair and equitable" to this class of creditors within the meaning of section $77 B(f)$ of the Bankruptcy Act, ${ }^{191}$ the predecessor of section 221 of the present Bankruptcy Act. ${ }^{102}$ The district court made a finding of fairness on the basis, among other things, that it would be an asset of value to the new company to retain the old Class A stockholders in the business because of their "familiarity with the operation" of the business, their "financial standing and influence in the community," and because they gave "continuity of management."103 After affirmance by the Court of Appeals, the Supreme Court granted certiorari because of the "contrariety ... in practical administration of the [Bankruptcy] Act among the circuits."194

186. Bonbright \& Bergerman, Two Rival Theories of Priority Rights of Security

Holders in a Corporate Reorganization, 28 CoLUM. L. Rev. 127 (1928).

187. See note 5 supra.

188. Bonbright \& Bergerman, supra note 186, at 153.

189. Case v. Los Angeles Lumber Co., 308 U.S. 106 (1939).

190. Consolidated Rock Prods. Co. v. DuBois, 312 U.S. 510 (1941).

191. 48 Stat. 919 (1934).

192. 52 Stat. 897 (1938), 11 U.S.C. \$ 621 (1958).

193. Case v. Los Angeles Lumber Co., 308 U.S. 106, 112-13 (1939).

194. Id. at 109. 
Speaking through Mr. Justice Douglas, the Supreme Court reversed. In a notable opinion, familiar to every reorganization lawyer, the Justice laid down these propositions: (1) if the plan is not fair and equitable as a matter of law the court cannot confirm it even though consents are obtained from the statutory majorities of the various classes of security holders; (2) the words "fair and equitable" as used in the statute are "words of art which prior to the advent of section $77 \mathrm{~B}$ had acquired a fixed meaning" through judicial interpretations in equity receivership reorganizations; (3) this "fixed principle" as enunciated in the Boyd and succeeding cases establishes the rule of "full and absolute priority" whereby, when the corporation is insolvent. the creditors are entitled to their full right of priority against the corporate assets; and (4) when the corporation is insolvent the junior creditor or shareholder's participation "must be based on a contribution in money or in money's worth, reasonably equivalent in view of all the circumstances to the participation of the stockholder." ${ }^{195}$ In this aspect, the supposed benefits accruing to the corporation from a continuance of the shareholders' participation did not fulfill the "reasonably equivalent" test. Moreover, Mr. Justice Douglas noted that although the relative priorities of the bondholders and the old Class A stockholders had been maintained "by virtue of the priorities accorded the preferred stock which the bondholders are to receive ...." this did not satisfy the "fairness" test. ${ }^{196}$ In view of this language, the case was hailed as establishing the rule of absolute priority and as marking the demise of the rule of relative priority. ${ }^{107}$ However, the total value of the assets did not exceed 25 per cent of the creditors' claim and they received nothing for the remainder; it is therefore doubtful that even the rule of relative priority as enunciated by Mr. Swaine had been satisfied. ${ }^{198}$

Although generally approving the tenor of the Los Angeles Lumber case, Professor Dodd, in a prescient article, pointed out a number of difficulties in its application. ${ }^{199}$ If the minority creditors may insist upon the exclusion of the shareholders from participation where there is a finding that insolvency exists, may they also insist that such participation shall not be permitted unless the district court affirmatively finds that solvency does exist? Where the issue of insolvency gives rise to honest doubts, cannot the question of the existence of assets in excess of debts be compromised on some reasonable basis, despite the objection of minority creditors? Furthermore, would there not be a tendency of the lower courts to give the junior creditors a break and circumvent the rule by taking an optimistic view of the "value" of the enterprise in view

195. Id. at 122 .

196. Id. at $119-20$.

197. See Note, Distribution of Securities in Corporate Reorganization, 51 YAlE L.J. $85,86(1941)$.

198. See Swaine, A Decade of Railroad Reorganization Under Section 77 of the Federal Bankruptcy Act, 56 HARv. L. Rev. 1193, 1205 (1943).

199. Dodd, The Los Angeles Lumber Products Company Case and Its Implications, 53 HARV. L. REv. 713 (1940). 
of that word's chameleonic character? And when solvency is found to exist, would the Court insist that the participation of the senior classes must be fully compensatory? If so, the practical necessity of obtaining the consent of the junior classes will often make it impracticable to compensate the senior security holders to the full extent of their claims. He predicted, therefore:

... that district judges who have found that a junior class does have an equity will find ways of sustaining reorganization plans which permit substantial participation by the members of that class, even where some blurring of what may seem to be the legal principles of the Los Angeles Co. case is necessary to justify the decision. It may also be surmised that, if the blurring of those principles is not made too apparent, such decisions will, for the most part, be sustained by circuit courts of appeals, and that petitions for certiorari addressed to the Supreme Court will be denied. Otherwise, the whole scheme for reorganization established by the Chandler Act will be made unworkable. ${ }^{200}$

Mr. Justice Douglas had another opportunity to clarify the scope of the absolute priority rule in the Consolidated Rock Products case. ${ }^{201}$ That case concerned the fairness of a plan of reorganization under section $77 \mathrm{~B}$ of a parent company and its two wholly-owned subsidiary corporations. Each subsidiary had outstanding bond issues with interest in default. Although the corporate entities of the subsidiaries had been preserved, pursuant to an operating agreement, the enterprise had been operated as a unit with commingling of assets, the parent undertaking to service the debt and settle accounts upon termination of the agreement. Under the plan of reorganization, bondholders of the subsidiary corporations were to receive income bonds and preferred stock for their claims to principal; however, their claims to accrued interest were to be extinguished without the receipt of any new securities. The preferred shares of the parent were to be allowed to participate by receiving one share of new common for each old share of preferred. This treatment rested upon a finding by the district court that the value of the assets of the three companies was in excess of the total bonded indebtedness of the subsidiaries, including accrued and unpaid interest. That court further determined, however, that it would be impossible to segregate the properties originally belonging to each company and arrive at the assets and earnings allocable to each class of securities. On this state of the record the district court found the plan fair and equitable.

When the case reached the Supreme Court Mr. Justice Douglas, writing for a unanimous court, disagreed with the district court and affirmed the Court of Appeals. He observed that under the applicable statute the district court must exercise an "informed, independent judgment" of the fairness of the plan. To discharge its responsibility, the court must make a finding of value "so that criteria will be available to determine an appropriate allocation of new securities between bondholders and stockholders in case there is an

200. Id. at 751-52.

201. 312 U.S. 510 (1941). 
equity remaining after the bondholders have been made whole."'202 The proper method of valuation, was by means of capitalization of prospective earnings. Furthermore, a determination of whether earnings may reasonably be expected to meet the earnings and dividend requirements of the new securities is a necessary element in a finding that the plan is not only "fair and equitable," but that it is feasible. It is also essential for satisfaction of the absolute priority rule, which applies to reorganizations of solvent as well as insolvent companies. As in the Los Angeles Lumber case, Mr. Justice Douglas took the view that the relative priorities had been maintained, because the bondholders had received for the principal amount of the old $6 \%$ bonds new $5 \%$ income bonds and preferred stock of an equal face amount. This view is questionable, however, since the proposed plan failed to compensate the bondholders for the loss of accrued interest. Although Douglas was of the view that the absolute priority rule does not mean that senior classes cannot be given inferior grades of securities to the old securities, or even securities of the same class as that received by the junior interests, they must "receive, in addition, compensation for the senior rights which they are to surrender."2n3 "Full compensatory provision must be made for the entire bundle of rights which the creditors surrender."204

After having said this, however, we are told that the method of effecting full compensation will vary depending upon the particular case. Then comes the puzzling statement which seems to leave everything up in the air:

[W] hether in case of a solvent company the creditors should be made whole for the change in loss of their seniority by an increased participation in assets, in earnings or in control, or in any combination thereof, will be dependent on the facts and requirements of each case. So long as the new securities offered are of a value equal to the creditors' claims, the appropriateness of the formula employed rests in the informed discretion of the court. ${ }^{205}$

There was obviously something of comfort to everyone - to the senior classes who could insist upon being "fully compensated" in new securities having a present market value equal to the face amount, including accrued interest on the old securities; and to the junior classes who could argue that the determination of a precise dollar value for the new securities was impossible, impracticable and never intended.

The Consolidated Rock Products case soon led to some startling results. A number of Section 77 railroad reorganizations had been wending their way through the Interstate Commerce Commission in the depression and post depression years. When the Western Pacific ${ }^{206}$ and Milwaukee ${ }^{207}$ cases

202. Id. at 524 .

203. Id. at 529 .

204. Id. at 528 .

205. Id. at 529-30.

206. In re Western Pac. R.R. Co., 124 F.2d 136 (9th Cir. 1941).

207. In re Chicago, M., St. P. \& P. R. Co., 124 F.2d 754 (7th Cir. 1942). 
reached the Courts of Appeal, the junior interests, dissatisfied with their lot, successfully attacked the findings of the Commission on the basis that it had failed to make specific findings of dollar values of the properties, old claims, and new securities as compelled by section 77 (e) of the Bankruptcy Act and the Consolidated Rock Products case. Under the circumstances the statute required either that the court dismiss the action or send it back to the Commission for further action. This not only meant further delay but cast a shadow over several other reorganizations of major railroads. ${ }^{208}$

At this point the Supreme Court took over the Western Pacific and Milwaukee cases, reversed the decisions of the Courts of Appeal and reinstated the orders of the district courts which had approved the plans of reorganization as certified by the Commission. Mr. Justice Reed wrote the opinion in Western Pacific, ${ }^{200}$ Mr. Justice Douglas in the Milkwaukee case. ${ }^{210}$

The two questions left open in Consolidated Rock Products were now put to rest. In the Milwaukee case, the Interstate Commerce Commission, in determining the permissible capitalization, had made an extensive review of the properties, business, and earnings of the debtor. It determined a maximum capitalization in a total dollar amount, after giving consideration to "the past and prospective earnings of the debtor and other relevant facts." It then determined the reasonable limits on fixed interest, new debt securities, and reasonable dividends to be paid on the new preferred, in the light of prospective earnings after taxes, and determined that the old preferred and common had "no value." Relying on the Consolidated Rock Products case, the junior classes contended that this did not satisfy the requirement of a specific finding as to value. To this Mr. Justice Douglas replied that since a valuation based on earning power is essentially a multi-factoral appraisal followed by a prediction for which there is no fixed formula, the Court could not say that the Commission had fallen into error or that the District Court's finding of "no value" was unjustified. ${ }^{211}$

As for the contention by senior classes that they were entitled to be fully compensated for the principal amount of their claims, including accrued and unpaid interest, by receiving new securities having a presently realizable equivalent market value, before the next junior class could participate, Mr. Justice Douglas had this to say:

A requirement that dollar values be placed on what each security holder surrenders and on what he receives would create an illusion of certainty where none exists and would place an impracticable burden on the whole

208. The alarm was sounded in Bourne, Findings of "Value" in Railroad Reorganizations, 51 YAlE L.J. 1057 (1942). And see Comment, Effect of the Consolidated Rock Products Decision on Railroad Reorganizations under Section 77, 51 YALE L.J. 967 (1942).

209. Ecker v. Western Pac. R.R., 318 U.S. 448 (1943).

210. Group of Institutional Investors v. Chicago, M., St. P. \& P. R.R., 318 U.S. 523 (1943).

211. Id. at 542 . 
reorganization process. See Bourne, Findings of "Value" in Railroad. Reorganizations, 51 Yale L.Journ. 1957. It is sufficient that each security holder in the order of his priority receives from that which is available for the satisfaction of his claim the equitable equivalent of the rights surrendered. That requires a comparison of the new securities allotted to him with the old securities which he exchanges to determine whether the new are the equitable equivalent of the old. But that determination cannot be made by the use of any mathematical formula. Whether in a given case senior creditors have been made whole or received "full compensatory treatment" rests in the informed judgment of the Commission and the District Court on consideration of all relevant facts. ${ }^{212}$

When the smoke had disappeared, Mr. Swaine, who had argued and won the Western Pacific case in the Supreme Court, summarized the "fixed principles" of the absolute priority rule this way:

Thus the fullness of the compensation or payment, the making whole, the application of the full value of the property, the absolute and strict recognition of priority, all seem to be positional or comparative - i.e. relative. Even in respect of relative positions in assets and earnings the words "absolute" and "strict" are to be taken in a much less "absolute" or "strict" sense than they might seem to imply. A senior securityholder may be given treatment in the same class of securities as is allotted to junior creditors provided the terms of the allotment to the senior creditors are sufficiently more favorable. This is evidenced not only by the actual treatment of the securities approved in the two cases but also by express language in both opinions.213

This post-depression battle has ended, but the war of words has yet to be resolved. The controversy, however, was largely one of semantics; and should another economic crisis arise, the degree of expected government involvement would in all probability make much of this learning irrelevant. ${ }^{214}$

2. Chapter $X$ or Chapter XI? We have already alluded to the clash between Chapter $\mathrm{X}$ and Chapter XI arising from the differences in origin and philosophy of these diverse roads for effecting a reorganization of a financially embarrassed corporation. ${ }^{215}$ In its original form Chapter $\mathrm{X}$ specifically provided that petitions for relief thereunder should be dismissed if "adequate relief would be obtainable" under Chapter XI. ${ }^{216}$ No comparable provision was contained in Chapter XI. In SEC v. United States Realty \& Inprove-

212. Id. at 565-66.

213. Swainte, supra note 198, at 1208-09.

214. See Blum, The Law and Langtiage of Corporate Reorganization, $17 \mathrm{U}$. CHI. L. Rev. 565 (1950); Billyou, Priority Rights of Security Holders in Bankruptcy Reorganization: New Directions, 67 HARv. L. Rev. 553 (1954) ; Blum, The "New Directions" for Priority Rights in Bankruptcy Reorganizations, 67 HARv. L. REv. 1367 (1954); Billyou, "New Directions": A Further Comment, 67 HaRv. L. Rev. 1379 (1954) ; Blum. Full Priority and Full Compensation in Corporate Reorganizations: A Reappraisal, 25 U. CHI. L. Rev. 417 (1958).

215. See text following note 113 supra.

216. See Bankruptcy Act, $\S \S 141,146(2), 52$ Stat. 887 (1938), 11 U.S.C. $\S 541,546$ (1958). 
ment Co., ${ }^{217}$ the Securities and Exchange Commission sought to block a middlesized, real estate investment company from utilizing Chapter XI to effect an arrangement with unsecured creditors, instead of complying with the more rigorous requirements of Chapter X. The debtor had 900,000 shares of common listed on the New York Stock Exchange and held by some 7,000 shareholders. Furthermore, the debt securities as to which the debtor sought an adjustment were owned by 900 creditors. The Supreme Court, Mr. Justice Douglas not participating, sustained the right of the Commission to intervene as a means of performing its "important public duties" under Chapter X. The Court emphasized the differences in purpose and function of the two chapters and concluded that it was incumbent upon a district court to measure the adequacy of relief available under each chapter "in the light of its effect on all the public and private interests concerned including those of the debtor."218 The court was of the view that the plan proposed would not meet the "fair and equitable" test of absolute priority as laid down in Los Angeles Lumber, since such protection could not be assured the unsecured creditors "without some re-arrangement" of the stockholders' rights. This was forbidden under Chapter XI and could only be effectuated under Chapter X. ${ }^{219}$

With this foothold, it appeared that the SEC was in a position to preserve the integrity of the reorganization process as embodied in its 1938 reform program in respect of large companies with widely held securities, resulting in the separation of ownership and control. Moreover, in 1952 Congress amended Chapter XI specifically to permit the Commission to intervene in Chapter XI proceedings and have the matter shifted to Chapter X, if the judge finds "that the proceedings should have been brought under Chapter $X$." 220 At the same time Congress amended section 366 so that confirmation of Chapter XI arrangements no longer hinges upon a finding that the plan is "fair and equitable" as well as feasible; $; 21$ the new test for confirmation requires only that the court be satisfied that the arrangement "is for the best interests of the creditors and is feasible." Furthermore, as if to underline the fact that the absolute priority rule of the Los Angeles Lumber case was no longer to be applicable by virtue of the elimination of the "fair and equitable" standard, a sentence was added specifying that confirmation shall not be refused "solely because ... if the debtor is a corporation, the interests of its stockholders or members will be preserved under the arrangement."222

In General Stores Corp. v. Shlensky, ${ }^{223}$ a debtor corporation petitioned under Chapter XI for an arrangement of its unsecured debts. None of the debts were evidenced by any publicly held security, although the corporation's

217. 310 U.S. 434 (1940).

218. Id. at 455 .

219. See note 114 supra.

220. 66 Stat. 432 (1952), 11 U.S.C. $\$ 728$ (1958).

221. 66 Stat. 433 (1952), 11 U.S.C. $\$ 766$ (1958).

222. Ibid.

223. 350 U.S. 462 (1956). 
over two million shares of common stock were listed on the American Stock Exchange and were held by over seven thousand shareholders. A single shareholder and the SEC moved to have the proceedings dismissed or shifted to Chapter X. The district court, relying on the United States Realty case, granted the request on the basis that court supervision over a reorganization of a corporation of this size and character was necessary; and the Court of Appeals affirmed by a divided court.

With Mr. Justice Douglas writing the opinion for the majority, the Supreme Court affirmed. The Court, however, rejected the factors of size and public ownership of the securities as the sole determinants of the choice between the two chapters.

It may well be that in most cases where the debtor's securities are publicly held c. X will afford the more appropriate remedy. But that is not necessarily so. A large company with publicly held securities may have as much need for a simple composition of unsecured debts as a smaller company. And there is no reason we can see why c. XI may not serve that end. The essential difference is not between the small company and the large company but between the needs to be served. ${ }^{224}$

The Court suggested various factors which the lower courts should take into account in deciding which chapter would best meet these needs: the need to investigate fraud or imprudent management, the past financial history, the complexities of the capital and debt structure, the classes of securities in need of adjustment, and the possibility of success of the arrangement without undue prejudice to creditors. Although the latter factor seems to include the absolute priority ingredient, Mr. Justice Douglas made no mention of the 1952 amendments to Chapter XI and their possible bearing upon the problem. Not so the dissenting opinion written by Mr. Justice Frankfurter; he read the 1952 amendments as compelling a more sympathetic judicial attitude toward Chapter XI. Since none of the creditors, and only a single shareholder and the Commission, had objected to the use of Chapter XI, it was his view that the district court had abused its discretion by diverting the proceeding to Chapter $\mathrm{X}$.

Whatever may be thought to be the preferable judicial approach to the problem, the indecisiveness and ambivalence of the majority opinion has been a source of confusion for the lower courts. Much seems to depend upon a judge's view of the efficacy of the "composition" approach to reorganizations with its latitude for "negotiations" between the various interests, on the one hand, or his conviction that the safeguards embodied in Chapter $\mathrm{X}$ have utility. ${ }^{225}$ This polarity of position most recently appeared in the Second

224. Id. at 466 .

225. No discernible pattern has developed in the lower courts. Dismissal under Chapter XI was directed in SEC v. Liberty Baking Corp., 240 F.2d 511 (2d Cir.), cert. denied, 353 U.S. 930 (1957); Mecca Temple, Etc. v. Darrock, 142 F.2d 869 (2d Cir.), cert. denied, 323 U.S. 784 (1944); In re Barchris Constr. Corp., 223 F. Supp. 229 (S.D. N.Y. 1963). Retention under Chapter XI was sustained in In re American Trailer Rentals Co., 325 F.2d 47 (10th Cir. 1963), cert. granted; Grayson-Robinson Stores, Inc. v. SEC, 
Circuit in Grayson-Robinson Stores, Inc. v. SEC. ${ }^{226}$ In that case the debtor corporation, a large retail chain, in 1961 underwent a change in top management as the result of the purchase of control shares by a new group. The new management immediately embarked upon a program of rapid expansion, relying primarily on short-term bank financing with a view to replacing it with long-term financing in a rising securities market, only to be caught short by the 1962 market collapse. The corporation petitioned for an arrangement of its unsecured obligations, in excess of twenty million dollars, under Chapter XI. The SEC resisted on the basis that debtor's difficulties had arisen from the ineptness of management and that public stockholders could best be protected by the appointment of an independent trustee and the application of the supervisory procedures of Chapter X. The debtor countered with selfserving affidavits of the corporate managers, trade creditors and labor representatives that the cumbersome procedures of Chapter X would make it impossible to retain "key employees" or obtain trade credit from suppliers of merchandise; and that the corporation would be unable to continue in business and pay its debts if reorganized under Chapter $\mathrm{X}$. On the strength of this "substantially uncontradicted factual showing," the trial court exercised its discretion to permit the Chapter XI arrangement to proceed and the Court of Appeals affirmed.

Judge Friendly, writing for the majority, found no clear principle to be derived from earlier cases, including those of the Supreme Court. Insofar as the United States Realty decision rested upon the "fair and equitable" foundation, it seemed to him a fair assumption that this had been undermined by the 1952 amendment eliminating the "fair and equitable" requirement from Chapter XI. He noted that this was the view of the minority in General Stores; to him the position of Mr. Justice Douglas, speaking for the majority on this point was not "altogether clear." 227 In any event, in the face of the uncontradicted evidence of the "drastic financial consequences of a transfer to Chapter $\mathrm{X}$ " - evidence that it was incumbent upon the SEC to come forward and rebut - he was not prepared to say the district court had abused its discretion.

On the other hand, the late Judge Clark, in one of his last opinions, dissented from these views in connection with the SEC's petition for rehearing en banc. ${ }^{228}$ To him the case presented all of the criteria emphasized by the Supreme Court in the United States Realty and General Stores decisions as requiring reorganizations under SEC supervision in Chapter $\mathrm{X}$ proceedings rather than

320 F.2d 940 (2d Cir. 1963); In re Lea Fabrics, Inc., 272 F.2d $769^{\prime}$ (3d Cir. 1959), vacated as moot, sub nom. SEC v. Lea Fabrics, Inc., 363 U.S. 417 (1960); SEC v. Wilcox-Gay Corp., 231 F.2d 859 (6th Cir. 1956) ; In re Transvision; Inc., 217 F.2d 243 (2d Cir. 1954), cert. denied, 348 U.S. 952 (1955).

226. 320 F.2d 940 (2d Cir. 1963). See also Comment, Discretion Properly. Exercised in Relying on Business Prospects to Allow Chapter XI Arrangement of Large Corporate Debtor, 64 ColuMr. L. Rev. 155 (1964).

227. 320 F.2d 940, 948 (2d Cir. 1963).

228. Id. at 950. 
in an unsupervised arrangement under Chapter XI. As for the 1952 amendments, the addition to section 328 codified the holding of United States Realty insofar as it related to SEC intervention. The addition to section 366 had nothing to do with the question of which chapter was to be required in a particular case; it dealt solely with the test for confirmation under Chapter $\mathrm{XI}$ after that choice had been made and the arrangement consummated as a substantive matter. To Judge Clark, this crucial decision put the law back "a quarter of a century." And with an oblique reference to recent "friendly criticism" of administrative agencies, not directed, however, at the SEC, ${ }^{229}$ Judge Clark concluded:

Now it appears that the battle for public supervision won in 1940 has all to be done again - if it can be rewon after this setback. It has been vigorously asserted that the regulatory agencies have been grievously at fault in not announcing rules and principles upon which they act. As concerns this agency, however, it would seem that it has had to expend so much of its time and energy in even maintaining a foothold on that regulation for which Congress had created it that it has little opportunity to build much beyond this. ${ }^{230}$

And so the matter rests for the moment. Unless there is a change in judicial attitude, or the SEC throws its front line troops into the fray and irons the kinks out of Chapter X procedures, or the Supreme Court lays down more specific guidelines, "the creditors groups who sponsored Chapter XI will have more than they bargained for, and the reformist aims of those who drafted Chapter X will be defeated."231 Curiously enough, Mr. Justice Douglas' opinion in the General Stores case has contributed significantly to this result.

3. Elevation of fiduciary standards. Although the Lea Bill, ${ }^{232}$ looking toward the reform of protective committees, failed to gain the support of Congress, some of its objectives have been achieved by the judicial gloss which the Court has placed on the Bankruptcy Act and by the infusion of equitable principles into bankruptcy jurisprudence. In these trends, Mr. Justice Douglas has been a major force. Through one of his early opinions the Court set aside a composition plan under which a municipality proposed to adjust its debts, because a fiscal agent retained by the city had interests which conflicted with those of other creditors and the facts had not been disclosed prior to the solicitation of their consents. The Court laid down the doctrine that a bankruptcy court, as a court of equity, must scrutinize the circumstances under which assent from a class of creditors is obtained; where such investigation

discloses the existence of unfair dealing, a breach of fiduciary obligations, profiting from a trust, special benefits for the reorganizers, or the need

229. See Friendiy, The Federal Adamnistrative Agencies (1962). For an earlier view of the reorganization process, see Friendly, Some Comments on the Corporate Reorganizations Act, 48 HARv. L. Rev. 39, 41-48 (1934).

230. 320 F.2d at 953 .

231. Rostow \& Cutler, supra note 113, at 1337.

232. See note 111 supra. 
for protection of investors against an inside few, or of one class of investors from the encroachments of another, the court has ample power to adjust the remedy to meet the need. ${ }^{233}$

The principle was later applied in a Chapter $\mathrm{X}$ proceeding to deny absolutely the claims of an indenture trustee, a bondholders' committee, and their counsel for fees and expenses, because in their respective roles they had assumed conflicting positions to various investor groups to whom they owed a duty of undivided loyalty. ${ }^{234}$

It will be recalled that under equity receivership reorganizations the practice had been to fix the fees and expenses by private arrangement, free of judicial control. ${ }^{235}$ In Chapter $\mathrm{X}$ proceedings, however, section 221 specifies that all payments for costs and expenses "by the debtor ... or by any other person" in connection with the proceedings are made subject to approval by the judge as a condition to confirmation. ${ }^{236}$ In Leiman v. Guttman, ${ }^{237}$ the Court, speaking through Mr. Justice Douglas, construed section 221 broadly to give the bankruptcy court exclusive jurisdiction over the reasonableness of compensation for services, costs or expenses, whether paid by the debtor or by outside sources pursuant to private arrangement. ${ }^{238}$ In contrast to Chapter $\mathrm{X}$, Chapter $\mathrm{XI}$ is more restrictive in allowance of compensation to committees or representatives of creditors or stockholders; yet it permits compensation for services to be paid from outside sources, free of judicial supervision. ${ }^{239}$ This enables legal counsel for the various interests to agree in advance as to fees and expenses and arrange for "excess" or noncompensatory payments to be made privately. ${ }^{240}$

The trend toward imposing a more rigorous fiduciary standard on persons involved in reorganization proceedings is exemplified by the recent case of Wolf $v$. Weinstein. ${ }^{241}$ The Court, speaking through $\mathrm{Mr}$. Justice Brennan,

233. American United Mut. Life Ins. Co. v. City of Avon Park, 311 U.S. 138, 146 (1940).

234. Woods v. City Nat'l Bank \& Trust Co., 312 U.S. 262 (1941). Cf. Dickinson Industrial Site, Inc. v. Cowan, 309 U.S. 382, 388 (1940) ; Brown v. Gerdes, 321 U.S. 178 (1944).

235. See note 86 supra and accompanying text.

236. 52 Stat. 897 (1938), 11 U.S.C. $\$ 621(4)$ (1958) (emphasis added).

237. 336 U.S. 1 (1949). Cf. SEC v. Drexel \& Co., 348 U.S. 341 (1955).

238. Mr. Justice Jackson dissented insofar as the decision purported to reach agreements between stockholders and counsel which did not affect funds of the estate or of a stockholders' protective committee. It seemed to him that the decision converted a statute "designed to prevent lawyers from overreaching stockholders into an authority for stockholders to swindle lawyers." 336 U.S. at 11.

239. Compare Bankruptcy Act, $\S \S 48,337$ [74 Stat. 198 (1960), 72 Stat. 821 (1958), 11 U.S.C. $\S \S 76$ (Supp. III, 1962), 737 (1958)], with §§ 221, 242 [52 Stat. 897, 900 (1958), 11 U.S.C. $\$ \S 621,642$ (1958)].

240. Rumors persist as to allocation of perquisites among members of the Bankruptcy establishment and of the fixing of fees in advance by mutual agreement. The statute invites such arrangements, whether or not such back scratching actually occurs in practice. There seems to be enough smoke to warrant legislative investigation.

241. 372 U.S. 633 (1963). 
construed section 249 of the Bankruptcy $\mathrm{Act}^{242}$ as requiring an officer and director of a debtor corporation in a Chapter $\mathrm{X}$ proceeding to disgorge profits made from trading in the stock of the debtor, without the consent or approval of the court. ${ }^{243}$ This line of decisions concerning compensation in reorganizations, as well as the application of the theory of absolute priority insofar as it limits the extent of participation by the junior classes of debt and shares, has removed some of the incentives for involvement of bankers and their counsel in masterminding reorganizations. The results of the cases have been arrived at through a blending of statutory and judicial controls over the reorganization process. Only Chapter XI remains as a possible avenue of escape.

\section{B. Securities Regulation}

Mr. Justice Douglas has written surprisingly few opinions in this field. Each case, however, has raised an important question of state or federal regulation, the members of the Court being sharply divided in their opinions.

At the state level, Travelers Health Ass'n. v. Virginia ex rel. State Corp. Comm'n., ${ }^{244}$ a 5-4 decision, raised the question of the power of Virginia to apply its Blue Sky Law to a Nebraska insurance association. The association conducted a mail order health insurance business in Virginia by inducing its old Virginia members gratuitously to solicit and forward applications for membership and insurance to the Nebraska home office. The Virginia Corporation Commission commenced cease and desist proceedings under the state statute which permitted services of process by registered mail upon the association in Nebraska. The Court, in an opinion by Mr. Justice Black, sustained the jurisdiction of Virginia against the claim of the insurance company that, since all of its activities were conducted outside of the state, service by registered mail offended due process conceptions. The majority opinion emphasized that the systematic solicitation of new prospects had established sufficient "minimum contacts" to satisfy "traditional notions of fair play and substantial justice," the standard developed in International Shoe. ${ }^{245}$ Although Mr. Justice Douglas concurred, he also wrote a separate opinion. He thought the problem was broader than that of the scope of procedural due process: it concerned the power of a state to enforce its securities laws against out-of-state issuers operating through the use of gratuitous agents within the state. $\mathrm{He}$ was not concerned with the amount of solicitation in quantitative terms: "Whether such solicitation is isolated or continuous, it is activity which Virginia can regulate."246 Mr. Justice Minton, with whom Mr. Justice Jackson joined, dissented on the ground that since the association had not been hurt - the

242. 52 Stat. 901 (1938), 11 U.S.C. $\$ 649$ (1958).

243. Mr. Justice Douglas voted with the majority. Mr. Justice Brennan's opinion is sprinkled with references to Douglas' earlier views as to the scope of $\$ 249$ while Chairman of the Securities and Exchange Commission.

244. 339 U.S. 643 (1950).

245. International Shoe Co. v. Washington, 326 U.S. 310, 316 (1945).

246. 339 U.S. 643,654 (1950) (concurring opinion). 
state only sought to publicize the cease and desist order - the procedural due process issue had not yet been reached. Justices Reed and Frankfurter agreed with the majority in reaching the merits, but on the merits joined the dissent. It is apparent from the four-way split that the dissenting Justices were fearful of a shift in doctrine along the lines suggested by Mr. Justice Douglas. Nevertheless, Professor Loss is quite correct in his view that Travelers Health "on its facts is not a square holding that the law of the state of the buyer's residence could not be constitutionally applied to a single isolated transaction of the type under discussion."247 At the same time, however, Loss saw "no good constitutional reason" against applying a non-resident securities statute framed along the lines of the non-resident motorists statutes $;^{248}$ and, as principal draftsman, he included such a provision in the Uniform Securities Act. ${ }^{240}$ The constitutionality of such a statute now seems secure as a result of the McGee case. ${ }^{250}$ The Minnesota supreme court has so held. ${ }^{251}$

At the federal level, SEC v. Variable Annuity Life Ins. Co., ${ }^{252}$ raised the question whether so-called "variable annuity" contracts written by some insurance companies are nonexempt "securities" under the Securities Act of 1933 and whether such companies were subject to the Investment Company Act of 1940. Section 3(a) (8) of the Securities Act exempts "insurance" and "annuity" contracts when "subject to the supervision of the insurance commissioner ... of any State. ..."253 Admittedly, this clause exempts the fixedreturn annuities, traditionally issued by insurance companies, under which the annuitant is to receive a definite periodic payment beginning at some future date. In recent years, however, the variable annuity has been developed as a hedge against inflation. Under this type of contract the annuitant makes periodic payments and receives an interest in a fund of common stocks and bonds. The periodic benefits payable to the annuitant vary with the financial success of the fund and of the insurance company's investment policy. The Court was of two minds as to whether these new "insurance" and "annuity" contracts were free of federal regulation by virtue of section $3(\mathrm{a})(9)$ and of the McCarran-Ferguson Act, ${ }^{254}$ which seeks to preserve to the states the regulation of the insurance business.

Mr. Justice Douglas wrote the majority opinion denying exemption from federal regulation. He believed the variable annuity contract lacked a basic

247. 1 Loss, Securities Regulation 80 (2d ed. 1961).

248. Ibid.

249. UnIform Securities Act $\S 414(\mathrm{~h}) ; 1$ Loss, op. cit. supra note 247 , at 89.

250. McGee v. International Life Ins. Co., 355 U.S. 220 (1957).

251. Paulos v. Best Securities Inc., 260 Minn. 283, 109 N.W.2d 576 (1961).

252. 359 U.S. 65 (1959).

253. Companies "organized as an insurance company, whose primary and predominant business activity is the writing of insurance . . . and which is subject to supervision by the insurance commissioner ... of a State" are exempt from the Investment Company Act, $\S \S 3(c)$ (3) and 2(a) (17), 54 Stat. 789 (1940), 15 U.S.C. $\S \S 80 \mathrm{a}-3$ (c) (3) and $80 \mathrm{a}-2$ (a) (17) (1958).

254. 59 Stat. 33 (1945), 15 U.S.C. $\$ \S 1011,1012$ (b) (1958). 
feature inherent in all "insurance," that there be "some investment risk-taking on the part of the company." ${ }^{555}$ There must be "a guarantee that at least some fraction of the benefits will be payable in fixed amounts." ${ }^{556}$ Thus, "there is no true underwriting of risks, the one earmark of insurance as it has commonly been conceived of in popular understanding and usage."257

In a concurring opinion, joined by Mr. Justice Stewart, Mr. Justice Brennan conceived the problem to be whether the variable annuitant needed the protections envisaged by the regulatory controls embodied in the Securities Act of 1933 and the Investment Company Act of 1940 or whether the state insurance regulation provided an adequate substitute. It was his view that although variable annuities embody certain features of traditional annuities, they essentially are so similar to contractual plan mutual funds that Congress in providing the $3(\mathrm{a})(8)$ exemption could not have intended that they be liberated from the federal regulatory scheme and left exclusively to state insurance regulation. ${ }^{258}$ Of the three opinions, Mr. Justice Brennan's contains by far the most penetrating analysis of the interaction of the two regulatory schemes, one devised for securities control, the other for the business of insurance. With all due deference, Mr. Justice Douglas' opinion is not the Justice at his best.

In Blau v. Lehman, ${ }^{259}$ the Court held Lehman Brothers, one of the great Wall Street investment banking firms, not to be subject to the recapture provisions of Section 16(b) of the Securities Exchange Act of 1934. The profits sought to be recovered were those received on the purchase and sale of securities of an issuer of which one of the Lehman partners was a director. Mr. Justice Black, speaking for the majority, believed the Court was precluded from holding that the partnership was also a "director" and thus subject to the Act on the basis of a finding by the two lower courts that the partnership did not deputize the partner serving as director to represent the firm. Mr. Justice Douglas wrote a strong dissent. ${ }^{260}$ It was inconceivable to him that the absence of formal approval of the representation was significantly different from informal approval of the relationship. "Everyone knows that the investment banking-corporation alliances are consciously constructed so as to increase the profits of the bankers." ${ }^{261} \mathrm{He}$ concluded: "What we do today allows all

255. SEC v. Variable Annuity Co., 359 U.S. 65, 71 (1959).

256. Ibid.

257. Id. at 73 .

258. Mr. Justice Harlan wrote a dissenting opinion, being joined by Justices Frankfurter, Clark and Whittaker. Curiously enough, Mr. Justice Frankfurter was one of the draftsmen of the Securities Act of 1933. His collaborator, Mr. James M. Landis, has since written that Mr. Justice Harlan misread the history of the Securities Act of 1933 in several respects. Landis, The Legislative History of the Securities Act of 1933, 28 GEo. WASH. L. REv. 29, 46 n.24 (1959).

259. 368 U.S. 403 (1962).

260. Chief Justice Warren concurred.

261. Blau v. Lehman, 368 U.S. 403, 415 (1962) (dissenting opinion). Cf. Wise, The Bustling House of Lehman, Fortune, Dec. 1957, p. 157. 
but one partner to share in the feast which the one places on the partnership table. They in turn can offer feasts to him in the 99 other companies of which they are directors."262 It remains to be seen how much comfort investment banking firms can derive from the Lehman case, in view of the possibility that other courts may not be equally charitable, and may be inclined to draw an inference of representation on similar facts. ${ }^{263}$

\section{Corporations}

Several of Mr. Justice Douglas' opinions have established new trends in the main currents of corporation law. ${ }^{264}$ Another opinion by Douglas in the antitrust field rests upon his application of state corporation law principles, ${ }^{265}$ and at least one of his dissenting opinions also falls within this general corporate field. ${ }^{200}$ Comment, however, will be limited to the impact of his opinions upon the evolving law of corporations.

Two companion cases involved the proper alignment of the corporation as party to the action in a shareholder's derivative suit brought in a federal court on the basis of diversity. It has long been established that for the purpose of obtaining federal jurisdiction in diversity suits there must be complete diversity between the plaintiffs, on the one hand, and defendants, on the other. ${ }^{267}$ A corporation has traditionally been regarded as a citizen of the state of incorporation, irrespective of the citizenship of its shareholders. ${ }^{268}$ Furthermore, the corporation is an indispensable party to any derivative suit, since any judgment for or against the corporation will be bindng upon it. ${ }^{269}$

The liberal venue ${ }^{270}$ and service of process ${ }^{271}$ provisions of the Judicial Code frequently enable a shareholder to prosecute a derivative suit in the

262. Blau v. Lehman, supra note 261 , at 420 (dissenting opinion).

263. For an analysis of the problem and a suggestion for corrective legislation, see Comment, Securities Regulation: Insider Statns in Legal Fiction and Financial FactA Proposed Revision to Section 16(b), 50 CaLtF. L. Rev. 500 (1962).

264. Pepper v. Litton, 308 U.S. 295 (1939) ; Anderson v. Abbott, 321 U.S. 349 (1944); Smith v. Sperling, 354 U.S. 91 (1957).

265. Melrose Distillers, Inc. v. United States, 359 U.S. 271 (1959) (dissolution of Maryland and Delaware corporations under indictment for violation of the Sherman Act does not abate the proceeding; under the applicable Maryland and Delaware statutes, their corporate lives continue so as to make them "existing" corporations within the meaning of $\$ 8$ of the Sherman Act). See also United States v. W. T. Grant Co., 345 U.S. 629, 636 (1953) (Douglas, J., dissenting), a case concerning interlocking directorates under $\$ 15$ of the Clayton Act.

266. See Cohen v. Beneficial Industrial Loan Corp., 337 U.S. 541, 557 (1949).

267. See Strawbridge v. Curtiss, 7 U.S. (3 Cranch) 267 (1806).

268. Louisville, C. \& C. RR. v. Letson, 43 U.S. (2 How.) 496 (1844). Since the 1958 amendments to the Judicial Code a corporation is also deemed to be a citizen of the state where it has its principal place of business. 28 U.S.C. \$ 1332 (1958).

269. Geer v. Mathieson Alkali Works, 190 U.S. 428 (1903).

270. 28 U.S.C. $\$ 1391$ (c) (1958) ; 28 U.S.C. \$ 1401 (1958).

271. Process in a stockholder's derivative action may be served upon the corporation in any judicial district where it is organized or is licensed to do business or is doing business. 28 U.S.C. $\$ 1695$ (1958). 
federal courts which he could not effectively maintain in any state court.272 For the purpose of determining whether complete diversity exists, however, the court will realign the parties according to their interests in the suit. ${ }^{273}$ The shareholder's suit is an invention of equity which allows the shareholderplaintiff to maintain the action on behalf of the corporation, if, after demand, the board of directors declines to bring the action. ${ }^{274}$ Under American practice the shareholder-plaintiff names the corporation as a formal defendant, even though it might be regarded as the actual plaintiff, ${ }^{275}$ since the action is brought for its benefit. In those cases where the corporation and the actual defendants are citizens of the same state, the realignment of the corporation as plaintiff would defeat diversity jurisdiction. More than fifty years ago, however, the Supreme Court laid down the rule that while normally in a derivative suit the corporation will be realigned as a plaintiff, if the corporation is under control of a board of directors antagonistic to the shareholder-plaintiff's interests so that he cannot get redress within the corporate structure, such realignment will not be necessary. ${ }^{270}$ The cases of Smith $v$. Sperling ${ }^{277}$ and Swanson $v$. Traer ${ }^{278}$ compelled a re-examination of the scope of this doctrine where the directors refuse to sue but assert that they are not hostile or antagonistic to corporate interests.

In Smith v. Sperling, a shareholder-plaintiff from New York brought a derivative action on behalf of $\mathrm{X}$ corporation of Delaware alleging a waste of corporate assets for the benefit of Sperling, a son-in-law of a director of the corporation, and $\mathrm{Y}$, the son-in-law's corporation, also of Delaware. The $\mathrm{X}$ corporation was named a defendant in the action. Plaintiff complained that certain agreements between $\mathrm{X}$ corporation and $\mathrm{Y}$ corporation were unfair to $\mathrm{X}$. Demand on the directors of $\mathrm{X}$ corporation to institute the action was not made, plaintiff alleging that demand would be futile, since a majority of the board had approved the contracts. After a fifteen day hearing the district court ruled that since there was no fraud on the part of the directors in making the contracts, but only the exercise of their independent business judgment, the management was not antagonistic to the financial interests of the corporation. Relying on Doctor $v$. Harrington, ${ }^{279}$ the court realigned $\mathrm{X}$ corporation as a plaintiff and dismissed the bill for want of diversity. Similarly, in Swanson $v$. Traer, the shareholder-plaintiff alleged fraud in the sale of corporate properties to another corporation in which some of the directors of the selling

272. See Dean v. Kellogg, 294 Mich. 200, 292 N.W. 704 (1940).

273. Koster v. Lumbermen's Mutual Co., 330 U.S. 518 (1947).

274. The federal courts developed certain equitable limitations upon a shareholder's standing to sue. See Hawes v. Oakland, 104 U.S. 450 (1881). These rules were codified in Equity Rule 94, 104 U.S. ix (1881), and eventually found their way into FED. R. CIV. P. 23(b).

275. See Groel v. United Electric Co., 70 N.J. Eq. 616, 61 Atl. 1061 (Ch. 1905).

276. Doctor v. Harrington, 196 U.S. 579 (1905).

277. 354 U.S. 91 (1957).

278. 354 U.S. 114 (1957).

279. 196 U.S. 579 (1905). 
corporation were personally interested and that, for this reason, demand on the directors would be futile. Although it clearly appeared that the directors were opposed to bringing the action, the Court of Appeals concluded that there was no hostility so as to create the requisite "antagonism." Accordingly, that court realigned the corporation as a plaintiff with the effect of defeating diversity jurisdiction.

When the cases reached the Supreme Court each was reversed in 5-4 decisions with $\mathrm{Mr}$. Justice Douglas writing for the majority. ${ }^{280} \mathrm{He}$ noted that the gist of the findings of the district court was that there was no antagonism between the management and the financial interest of the corporation because a non-fraudulent independent business judgment had been exercised. This, Douglas argued, was not a jurisdictional question. The charge is normally cast in terms of some illegality and the answer always denies it. To settle that conflict necessarily involves examination of the merits - a wasteful expenditure of energy on a preliminary issue in the case.

Mr. Justice Frankfurter wrote a dissenting opinion in which Justices Burton, Harlan and Whittaker concurred. To him the decisions overturned "a half-century's precedents" of the Court. He would apparently align the corporation as a plaintiff unless at least a majority of the directors are implicated or are under the dominance of the actual defendants; indeed, unless "the very individuals who have a stranglehold over the corporation are the people against whom the suit is sought to be brought. . . ."281 This view, he believed, was compelled by Article III of the Constitution; that unless such antagonism existed between the corporation and its management there was no "controversy" between plaintiff-shareholder and the corporation which would require that the corporation be aligned as defendant. With all due deference to the learned Justice, this line of argument takes a wholly unrealistic view of the nature of the corporate structure and the conflicting positions of a plaintiffshareholder and management in this type of derivative suit. Moreover, the rule advocated by the dissenting Justices would render effective prosecution of legitimate grievances in the state courts impracticable in many situations because of constitutional barriers relating to venue and service of process. Accordingly, there appears to be no compelling reason for favoring state courts over federal courts in this situation.

Among the most controversial of Mr. Justice Douglas' opinions is that in Anderson v. Abbott, ${ }^{282}$ raising the question whether the use of a bank-stock holding company to hold bank shares insulated the shareholders of the holding company from statutory double liability formerly imposed upon the holders of bank stocks. ${ }^{283}$ Banco, the holding company, had been organized in 1929

280. Smith v. Sperling, 354 U.S. 91 (1957) ; Swanson v. Traer, 354 U.S. 114 (1957).

281. 354 U.S. at 104.

282. 321 U.S. 349 (1944).

283. The Bank Act formerly provided:

The shareholders of every national banking association shall be held individually responsible . . . for all contracts, debts, and engagements of such association, to 
by the management of the National Bank of Kentucky and the Louisville Trust Company to perfect an alliance between Bank and Trust Company. The union was accomplished by having Banco acquire most of Bank and Trust Company shares in exchange for its shares. Some of the shareholders participating in the exchange purchased additional shares of Banco for cash. Banco also sold additional stock to other individuals for cash; and most of these funds were invested in Bank shares. In a little more than a year Bank and Trust Company failed causing Banco to topple also. The Comptroller of the Currency levied a double liability assessment against Banco as the holder of substantially all of Bank's shares. Having obtained only partial satisfaction from Banco, the Bank receiver sought to recover from each shareholder of Banco his pro rata part of the balance of the assessment based upon his shareholdings in Banco. The district court found that Banco had been formed in good faith, was not a sham, had not been formed as a means of avoiding double liability, and dismissed the bill. The Court of Appeals agreed and affirmed.

In another 5-4 opinion, the Court, with Mr. Justice Douglas as spokesman, reversed. In his view, the former shareholders of the Bank who exchanged their shares for Banco shares retained through Banco their former investment position in the Bank, including control, and did not constitute Banco as an adequate financial substitute. To allow them to thus escape liability would contravene the policy of the law underlying statutory double liability. The main assets of the holding company were stocks in banks which carried a double liability, and there were no free assets which would constitute an adequate reserve against the double liability on the bank stocks. Moreover, he saw no substantial distinction between the former shareholders of the Bank and those individuals who purchased shares of Banco for cash. A purchases underlying bank shares for $\$ 10,000$ and exchanges those shares for shares of Banco; $\mathrm{B}$ buys Banco shares for $\$ 10,000$ and Banco invests these funds in shares of an underlying bank.

From the practical point of view $A$ and $B$ are investors of the same class. To say that $A$ is liable and $B$ not liable when both start with cash and end with identical investments is to make the difference between liability

the extent of the amount of their stock therein, at the par value thereof, in addition to the amount invested in such shares; ... 12 U.S.C. $\$ 63$.

The stockholders of every national banking association shall be held individually responsible for all contracts, debts, and engagements of such association, each to the amount of his stock therein, at the par value thereof in addition to the amount invested in such stock. The stockholders in any national banking association who shall have transferred their shares or registered the transfer thereof within sixty days next before the date of the failure of such association to meet its obligations, or with knowledge of such impending failure, shall be liable to the same extent as if they had made no such transfer, to the extent that the subsequent transferee fails to meet such liability; but this provision shall not be construed to affect in any way any recourse which such shareholders might otherwise have against those in whose names such shares are registered at the time of such failure. 12 U.S.C. § 64. 
and no liability turn on distinctions which have no apparent relevancy to the legislative policy which the rule of double liability was designed to protect. And to say that courts may hold A liable but not $B$ is to make the occasions for the assertion of judicial power turn on whimsical circumstances. ${ }^{284}$

Mr. Justice Jackson wrote a stinging dissent, in which Justices Roberts, Reed and Frankfurter concurred. He conceded that there might be some basis for holding the former shareholders of the Bank liable. In spite of the exchange of Bank shares, its stockholders, through the holding company, retained a large measure of control over the Bank as well as the benefits of investment in it. Accordingly, if examination of the evidence should warrant it, the Court might reach the legal conclusion that double liability of the shareholders of the Bank survived the exchange. This, however, would be on the theory that the former shareholders were liable as stockholders of the bank, whereas the Court was holding them subject to a different and smaller liability as stockholders of the holding company. At the same time the Court was concluding that the purchasers of the holding company stock for cash had acquired a substitute double bank stock liability proportionate to their investment in the holding company. Thus, in his view, the grounds for liability of the Bank stockholders and the non-Bank stockholders were inconsistent. "If the new stockholders for cash are liable it is hard to see why the old ones have not found a substitute, and if the Bank ... stockholders have not found a substitute, it is difficult to see a basis on which the new stockholders are liable." 285 In any event, since the new stockholders never at any time owned shares in a national bank it was impossible to understand how their action defeated any federal policy concerning national banks. Congress had declared no such policy; and the Court was engaging in judicial legislation. ${ }^{286}$ A survey of newspaper sentiment evoked by the decision and the strongly worded dissent was taken shortly after the case was handed down; it reflects a good deal of turmoil over the role played by both majority and dissent in "legislative matters."287 Although double bank stockholder liability has long since been

284. Anderson v. Abbott, 321 U.S. 349, 367 (1944).

285. Id. at 372 (dissenting opinion).

286. Id. at 379-83 (dissenting opinion).

287. The reactions of the daily press were greatly influenced by the language of the minority. With the only discovered exception of St. Louis, Mo., Star-Times, March 7, 1944, which took the view that "the majority clearly observed the bounds of the law," newspapers seem to have taken the charge of usurpation of legislative functions at its face value. They spoke of "government by decree" [San Diego, Calif., Union, March 7, 1944], "justice by ear" [Wall Street Journal, March 8, 1944], "courts of ideology" [Washington, D. C., Post, March 10, 1944], and, of course, "judicial legislation" [Washington, D. C., Star, March 7, 1944]. But while using the arguments of the minority, the editorials did not spare it in their attacks. They spoke of charges of "exclusive blackness between pot and kettle" [Journal of Commerce, March 8, 1944], noted that "certain members of the court have shown uncertainty of conviction by being first on one side of the fence and then on the other" [Colo. Springs, Colo., Gazette, March 13, 1944], found it "interesting to 
supplanted by a system of deposit insurance, Anderson v. Abbott still stands for the proposition that a strong legislative policy may not be thwarted by the use or misuse of the corporate form. ${ }^{288}$

There remains only to consider Mr. Justice Douglas' opinion in Pepper v. Litton, ${ }^{289}$ written early in his judicial career when the Justice's interest in and enthusiasm for the work of the Court was at its height. Of all his opinions, this in all probability has had the greatest influence upon the law of corporations. To me, it is a superb opinion, the Justice at his best. The case basically raises a bankruptcy problem. It concerned one Litton who sought to use a "one-man" corporation to defraud Pepper, a creditor of the corporation. Pepper had brought suit against the debtor corporation in a state court to recover royalties due under a lease. While the suit was pending, Litton caused the corporation to confess a judgment in his favor in the amount of $\$ 33,000$ representing accumulated salary claims. Execution was issued but Litton, apparently with the aid of the Sheriff, waited for the outcome of the Pepper suit. When Pepper obtained a state court judgment against the corporation for $\$ 9,000$, Litton obtained time to take an appeal, but executed on his judgment against the corporation and purchased corporate property at the execution sale for $\$ 3,200$. This property was then transferred to another one-man corporation in exchange for its stock. The debtor corporation thereupon filed a voluntary petition in bankruptcy. It had assets of $\$ 16,500$ and Litton's remaining claim was for almost $\$ 30,000$. Litton then proceeded to buy up all remaining claims against the debtor corporation, except the Pepper claim. In further state court litigation in which Pepper sought to have the Litton judgment declared void, the state court held that at one stage of these proceedings Pepper, and the trustee in bankruptcy, who was representing Pepper as the only creditor, had treated the fund derived from the execution sale under the Litton judgment as valid, and therefore were estopped to attack it. When the question of the allowance of the Litton judgment came before the bankruptcy court, however, the court found on the facts that there had been a deliberate attempt to avoid the payment of a just debt and disallowed the claim. On appeal, the Circuit Court reversed, holding that the state court judgment was res judicata in the bankruptcy proceedings. The Court, in an unanimous opinion written by Mr. Justice Douglas, reversed.

have a minority, particularly when that includes Justice Felix Frankfurter, accuse the court of making laws" [Indianapolis, Ind., Star, March 8, 1944; Muncie, Ind., Star, March 9, 1944] and observed that the dissenters "apparently now place the Constitution above the New Deal" [Salem, Ore., Journal, March 7, 1944]. Some dailies saw in the instant case the result of "packing the Supreme Court with supposedly New Deal political stooges" and an episode of the Executive's usurpation of both legislative and judicial functions. . . .

Note, 44 Colum. L. Rev. 561,565 n.30 (1944).

288. Cf. United States v, Milwaukee Refrigerator Transit Co., 142 Fed. 247 (C.C. E.D. Wis. 1905). But see United States v. Elgin, J., \& E. Ry., 298 U.S. 492 (1936); United States v. South Buffalo Ry. Co., 333 U.S. 771 (1948).

289. 308 U.S. 295 (1939). 
The main thrust of the Douglas opinion is that a bankruptcy court is essentially a court of equity; it is granted the power to allow or disallow claims; and in the exercise of its equitable powers it may disallow or subordinate claims "to the end that fraud will not prevail, that the substance will not give way to form, that technical considerations will not prevent substantial justice from being done."200 This equitable power exists to pass upon claims of an officer, director and stockholder in bankruptcy proceedings against his corporation. Then comes a statement of the fiduciary obligations of officers, directors and controlling stockholders, that has become a classic quotation on the duties of these persons not only to the corporation, ${ }^{291}$ as such, but to the shareholders, and in the event of insolvency, to the creditors as well.

A director is a fiduciary. ... So is a dominant or controlling stockholder or group of stockholders. . . . Their powers are powers in trust. Their dealings with the corporation are subjected to rigorous scrutiny and where any of their contracts or engagements with the corporation is challenged the burden is on the director or stockholder not only to prove the good faith of the transaction but also to show its inherent fairness from the viewpoint of the corporation and those interested therein. The essence of the test is whether or not under all the circumstances the transaction carries the earmarks of an arm's length bargain. If it does not, equity will set it aside. While normally that fiduciary obligation is enforceable directly by the corporation, or through a stockholder's derivative action, it is, in the event of bankruptcy of the corporation, enforceable by the trustee. For that standard of fiduciary obligation is designed for the protection of the entire community of interests in the corporation creditors as well as stockholders. ...

... He who is in such a fiduciary position cannot serve himself first and his cestuis second. He cannot manipulate the affairs of his corporation to their detriment and in disregard of the standards of common decency and honesty. He cannot by the intervention of a corporate entity violate the ancient precept against serving two masters. He cannot by the use of the corporate device avail himself of privileges normally permitted outsiders in a race of creditors. He cannot utilize his inside information

290. Id. at 305.

291. Jenks traces the importance of the development of equity reform in English common law and concludes that in England this process of adjusting the law to make it' responsive to social needs came to an abrupt termination in the last quarter of the eighteenth century. The second of his examples touches on the fiduciary relationship of corporate managers to the shareholders:

The second example is that of the company promoter or director, who shields himself from liability towards his real beneficiaries, the shareholders, behind the artificial protection of that purely legal entity, the company. With a reasonable application of equitable principles, the monstrous doctrine: that "the directors of a company are not trustees for individual shareholders," would never have been adopted; and directors who are secretly negotiating a profitable sale of their company's assets would not be allowed to go about buying up shares with a view to profiting at the expense of their own shareholders. The Court which decided Keech v. Sandford [(Ch. 1726) Sel. Cas. Ch. 61] would have made short work of a claim such as that. [Footnotes omitted.]

Jenks, A Short History of Engitsh Law 240 (6th ed. 1949). 
and his strategic position for his own preferment. He cannot violate rules of fair play by doing indirectly through the corporation what he could not do directly. He cannot use his power for his personal advantage and to the detriment of the stockholders and creditors no matter how absolute in terms that power may be and no matter how meticulous he is to satisfy technical requirements. For that power is at all times subject to the equitable limitation that it may not be exercised for the aggrandizement, preference, or advantage of the fiduciary to the exclusion or detriment of the cestuis. Where there is a violation of those principles, equity will undo the wrong or intervene to prevent its consummation. ${ }^{292}$

In a very real sense this passage epitomizes the Justice's basic philosophy of corporate regulation. This conception of fiduciary obligation, the insistence on the ancient precept that no man can serve two masters, is a theme that has pervaded his thinking in this field as teacher, government servant and judge.

\section{CONCLUSION}

In 1925, when Douglas launched his teaching career, the regulation of corporate enterprise depended primarily upon state statutes supplemented by judicial controls based on equitable principles. The corporation statutes of the more "liberal" states were then as they are today, essentially enabling acts containing many loopholes for an irresponsible management and few provisions for the protection of shareholders. Added to this was the freedom to choose the state of incorporation, regardless of where the business is to be conducted. Moreover, securities regulation was entirely dependent upon state action. With the tremendous growth in the number and size of corporations and the interstate nature of the economy, the old system of state regulation was found to be completely inadequate to meet the economic and social crisis precipitated by the great depression.

The emergence of the American system of corporate regulation since that time parallels the growth and development of the man. Chairman William L. Cary of the Securities and Exchange Commission has recently reminded us that "the securities acts may be said to have generated a wholly new and far-reaching body of Federal corporation law."293 Douglas of the Securities and Exchange Commission was one of the chief architects of that system. And as a member of the highest court he has played a crucial role in the development of judicial doctrines which for many purposes have created a new federal law of relations between management and investors. ${ }^{294}$

The poet has said: "Bring me men to match my mountains." was such a man. On this, the silver anniversary of his service on the Supreme Court, the country can salute him : "Well done, thou good and faithful servant."

292. Pepper v. Litton, 308 U.S. 295, 306-11 (1939).

293. Cady, Roberts \& Co., 40 S.E.C. 907,910 (1961).

294. Cf. McClure v. Borne Chemical Co., 292 F.2d 824, 834 (3d Cir.), cert. denied, 368 U.S. 939 (1961).

295. Sam Walter Foss, The Coming American. 